Article

\title{
Rice Bran and Vitamin B6 Suppress Pathological Neovascularization in a Murine Model of Age-Related Macular Degeneration as Novel HIF Inhibitors
}

\author{
Mari Ibuki ${ }^{1,2,+}$, Deokho Lee ${ }^{1,2,+} \mathbb{D}$, Ari Shinojima ${ }^{1,2,+}$, Yukihiro Miwa ${ }^{1,2,3} \mathbb{D}^{\mathbb{D}}$, \\ Kazuo Tsubota $2,4, *$ (D) and Toshihide Kurihara $1,2, *$ (D) \\ 1 Laboratory of Photobiology, Keio University School of Medicine, Tokyo 160-8582, Japan; \\ shirayuki0727@yahoo.co.jp (M.I.); deokholee@keio.jp (D.L.); ari.shinojima@keio.jp (A.S.); \\ yukihiro226@gmail.com (Y.M.) \\ 2 Department of Ophthalmology, Keio University School of Medicine, Tokyo 160-8582, Japan \\ 3 Animal Eye Care Tokyo Animal Eye Clinic, Tokyo 158-0093, Japan \\ 4 Tsubota Laboratory, Inc., Tokyo 160-0016, Japan \\ * Correspondence: tsubota@tsubota-lab.com (K.T.); kurihara@z8.keio.jp (T.K.); \\ Tel.: +81-3-5636-3269 (K.T.); +81-3-5636-3204 (T.K.) \\ + These authors contributed equally to this work.
}

Received: 10 November 2020; Accepted: 24 November 2020; Published: 25 November 2020

\begin{abstract}
Pathological neovascularization in the eye is a leading cause of blindness in all age groups from retinopathy of prematurity (ROP) in children to age-related macular degeneration (AMD) in the elderly. Inhibiting neovascularization via antivascular endothelial growth factor (VEGF) drugs has been used for the effective treatment. However, anti-VEGF therapies may cause development of chorioretinal atrophy as they affect a physiological amount of VEGF essential for retinal homeostasis. Furthermore, anti-VEGF therapies are still ineffective in some cases, especially in patients with AMD. Hypoxia-inducible factor (HIF) is a strong regulator of VEGF induction under hypoxic and other stress conditions. Our previous reports have indicated that HIF is associated with pathological retinal neovascularization in murine models of ROP and AMD, and HIF inhibition suppresses neovascularization by reducing an abnormal increase in VEGF expression. Along with this, we attempted to find novel effective HIF inhibitors from natural foods of our daily lives. Food ingredients were screened for prospective HIF inhibitors in ocular cell lines of 661W and ARPE-19, and a murine AMD model was utilized for examining suppressive effects of the ingredients on retinal neovascularization. As a result, rice bran and its component, vitamin B6 showed inhibitory effects on HIF activation and suppressed VEGF mRNA induction under a $\mathrm{CoCl}_{2}$-induced pseudo-hypoxic condition. Dietary supplement of these significantly suppressed retinal neovascularization in the AMD model. These data suggest that rice bran could have promising therapeutic values in the management of pathological ocular neovascularization.
\end{abstract}

Keywords: hypoxia-inducible factor; age-related macular degeneration; vascular endothelial growth factor; food ingredients; rice bran; vitamin B6; retinal pigment epithelium

\section{Introduction}

Ocular pathological neovascularization is a leading cause of blindness worldwide [1,2]. It affects our lives in all age groups from children to elderly with various names of diseases such as retinopathy of prematurity (ROP), diabetic retinopathy (DR), retinal vein occlusion and age-related macular degeneration (AMD) [3]. To date, a blockade of vascular endothelial growth factor (VEGF) using anti-VEGF antibodies has been applied for the treatment of these diseases [4], as VEGF plays a crucial 
pathological role in the development of these diseases [5,6]. Even though small concentrations for the treatment to a local target site may not affect systemic side effects of the drugs, repetitive administrations of anti-VEGF drugs for chronic therapies could alter a systemic or local VEGF amount which may be required for normal vascular and neuronal maintenance [4]. Moreover, anti-VEGF drugs are still ineffective in some cases, especially in patients with AMD [7].

Hypoxia-inducible factor (HIF) plays a strong transcription regulator of VEGF induction under hypoxic and other stress conditions [8]. Under hypoxic conditions, HIF translocates to the nucleus and binds the hypoxia response element (HRE), inducing hypoxia responsive gene expressions including VEGF as well as B-cell lymphoma 2 interacting protein 3 (BNIP3) and phosphoinositide-dependent kinase 1 (PDK1) [9,10]. As the HIF/VEGF axis is a strong pathological pathway for neovascularization [11,12], inhibiting HIF activation could be an attractive target for antineovascularization therapies. Moreover, HIF expression was observed in human choroidal neovascular membranes in patients with AMD [13,14], and retinal pigment epithelial (RPE) cells resided in those membranes were localized with the presence of HIF and VEGF [14].

Previously, we demonstrated HIF inhibition-suppressed retinal neovascularization genetically and pharmacologically in murine models of oxygen-induced retinopathy (OIR), one of the ROP models, and laser-induced choroidal neovascularization (CNV), one of the AMD models [15-19]. Moreover, another HIF inhibitor, halofuginone, a synthetic derivative of febrifugine isolated from hydrangea, exerted retinal protection in a murine ischemia-reperfusion model [20].

In our daily lives, we consume extensive amounts of food. Even though food has been classically perceived as a simple means for energy production and body construction, their potentials have expanded to drug discovery and development for various diseases [21-23]. Diet that contains omega-3 fatty acids could enhance cognitive functions in humans [24]. A suggestive association of a vegetable-rich and low carbohydrate diet and a lower risk of early paracentral visual loss in primary open-angle glaucoma was recently reported in data from three United States cohorts [25]. There are still lots of food ingredients that could be unraveled in terms of potent therapeutic effects that they possess on various diseases including retinal neovascularization.

Along with this, we obtained various types of food ingredients and attempted to find novel effects of them through drug screenings: inhibitors of HIF activation. After screenings, we investigated therapeutic effects of positively selected ingredients on retinal neovascularization in a murine model of laser-induced CNV.

\section{Materials and Methods}

\subsection{Animal}

All experimental procedures were approved by the Ethics Committee on Animal Research of the Keio University School of Medicine (approved number \#16017-2 on 12 October 2018) and followed with the ARVO Statement for the Use of Animals in Ophthalmic and Vision Research and the international standards of animal care and use in ARRIVE (Animal Research: Reporting in Vivo Experiments) guidelines (http://www.nc3rs.org.uk/arrive-guidelines). C57BL/6 and BALB/c male mice were obtained from CLEA Japan (Tokyo, Japan) and raised in a standardized temperature-controlled environment under a $12 \mathrm{~h}$ light-dark cycle with free access to water and food.

\subsection{Cell Culture}

A mouse cone photoreceptor 661W cell line was maintained in DMEM (Cat \#08456-36, Nacalai Tesque, Kyoto, Japan) media with $10 \%$ FBS and 1\% streptomycin-penicillin under an atmospheric condition containing $5 \% \mathrm{CO}_{2}$ at $37^{\circ} \mathrm{C}$. A human cell line for retinal epithelial ARPE- 19 was maintained in DMEM/F-12 (Cat \#C11330500BT, Gibco, Waltham, MA, USA) media with the same supplements above in the same atmospheric condition. 


\subsection{Food Ingredient Preparation and Luciferase Assay}

Food ingredients for the screening were prepared as listed in Table A1. Then, a luciferase assay for drug screenings on inhibition of HIF activation was performed as previously described in our papers [15-17,20]. Briefly, 661W and ARPE-19 cells, transfected with a HIF-luciferase reporter gene construct (Cignal Lenti HIF Reporter, Qiagen, Venlo, Netherlands) encoding a firefly luciferase gene under a control of the HRE, were seeded and treated with a well-known HIF inducer $\mathrm{CoCl}_{2}(200 \mu \mathrm{M}$, cobalt (II) chloride hexahydrate, Wako, Osaka, Japan). To evaluate inhibitory effects of food ingredients on HIF activation, cells were cotreated with $1 \mathrm{mg} / \mathrm{mL}$ of each ingredient and $\mathrm{CoCl}_{2} .24 \mathrm{~h}$ after incubation, luminescence was measured using Dual-Luciferase Reporter Assay System (Promega, Madison, WI, USA).

\subsection{MTT Assay}

For determination of cytotoxicity of food ingredients under a $\mathrm{CoCl}_{2}$-induced hypoxic condition, ARPE-19 cells were seeded in 96-well plates and the ingredients were treated to the cells for $12 \mathrm{~h}$. A total of $10 \mu \mathrm{L}$ of MTT solution (Cat \#M2128, Sigma, St. Louis, MO, USA) was added to each well and incubated for $2 \mathrm{~h}$ at $37^{\circ} \mathrm{C}$. After labeling the cells with MTT, media were removed from the wells and $100 \mu \mathrm{L}$ of DMSO was added to each well. Then, absorbance of colored solution in the wells was measured at $540 \mathrm{~nm}$ (Synergy HT Multi-Mode Microplate Reader, Winooski, VT, USA).

\subsection{Quantitative PCR and Western Blotting}

RNA extraction, cDNA synthesis and real-time quantitative PCR were performed as same as previously described in our papers $[15-17,20]$. Primers used are listed in Table 1 . Fold changes between levels of different transcripts were calculated by the $\Delta \Delta C_{T}$ method.

Table 1. Primer list.

\begin{tabular}{ccc}
\hline Name & Direction & Sequence $\left(\mathbf{5}^{\prime} \rightarrow \mathbf{3}^{\prime}\right)$ \\
\hline \multirow{2}{*}{ GAPDH } & Forward & TCCCTGAGCTGAACGGGAAG \\
& Reverse & GGAGGAGTGGGTGTCGCTGT \\
\hline \multirow{2}{*}{$H I F-1 \alpha$} & Forward & TTCACCTGAGCCTAATAGTCC \\
& Reverse & CAAGTCTAAATCTGTGTCCTG \\
\hline \multirow{2}{*}{$V E G F$} & Forward & TCTACCTCCACCATGCCAAGT \\
& Reverse & GATGATTCTGCCCTCCTCCTT \\
\hline \multirow{2}{*}{ BNIP3 } & Forward & GGACAGAGTAGTTCCAGAGGCAGTTC \\
& Reverse & GGTGTGCATTTCCACATCAAACAT \\
\hline \multirow{2}{*}{ PDK1 } & Forward & ACAAGGAGAGCTTCGGGGTGGATC \\
& Reverse & CCACGTCGCAGTTTGGATTTATGC \\
\hline
\end{tabular}

Protein extraction, electrophoresis and visualization of protein bands were performed as the same as previously described in our papers $[15-17,20]$. Antibodies used were anti-HIF-1 $\alpha$ (1:1000, Cat \#36169, Cell Signaling Technology, Danvers, MA, USA), anti-HIF-2 $\alpha$ (1:1000, Cat \#NB100-122, Novus Biologicals, Centennial, CO, USA) and anti- $\beta$-Actin (1:5000, \#3700, Cell Signaling Technology, Danvers, MA, USA). For visualization, HRP-conjugated secondary antibodies (1:5000, GE Healthcare, Chicago, IL, USA) were used. Blotting was quantified using NIH ImageJ software (National Institutes of Health, Bethesda, MD, USA).

\subsection{A Laser-Induced CNV Model and Measurement of CNV Volumes}

A murine laser-induced $\mathrm{CNV}$ model was produced as previously described in our papers $[15,16]$. Briefly, the eyes of C57BL/6 mice were dilated by a combination of $0.5 \%$ tropicamide and $0.5 \%$ phenylephrine (Santen Pharmaceutical, Osaka, Japan) and the mice were anesthetized by a combination 
of midazolam (Sandoz, Tokyo, Japan), medetomidine (Orion, Espoo, Finland) and butorphanol tartrate (Meiji Seika Pharma, Tokyo, Japan), termed 'MMB'. After anesthesia, the eyes of mice were covered with a contact lens (Haag-Streit Diagnostics, Koniz, Switzerland) to see the retinas clearly. A total of 5 laser spots ( $532 \mathrm{~nm}$ argon laser, $200 \mathrm{mw}, 100 \mathrm{~ms}, 75 \mathrm{~mm}$ ) were placed between the retinal vessels, located 2-disc diameters from the optic nerve head. During irradiation by laser, an air bubble was used as an index of Bruch's membrane disruption. Laser lesions that lack the air bubble or have occurrence of hemorrhage were excluded from data analyses $[15,16]$. At day 7 after irradiation, the mice were anesthetized by $\mathrm{MMB}$, followed by euthanasia, and the eyes were enucleated by forceps. The retinas from the eyes were flat-mounted and stained with isolectin B4 (Invitrogen, Carlsbad, CA, USA) [15,16]. We observed CNV with a laser microscope (Zeiss, Oberkochen, Germany) and measured a volume of CNV using Imaris (Bitplane, Zurich, Switzerland) as previously described in our papers $[15,16]$.

\subsection{A Light-Induced Retinopathy (LIR) Model and Measurement of Retinal Function by Electroretinography (ERG)}

Development of a murine light-induced retinopathy (LIR) model was modified from our previous study [26], the exposure of 3000 lux white light to the eyes for $1 \mathrm{~h}$. After 1 week following the light exposure, the eyes of $\mathrm{BALB} / \mathrm{c}$ mice were dilated by a combination of $0.5 \%$ tropicamide and $0.5 \%$ phenylephrine (Santen Pharmaceutical, Osaka, Japan) and the mice were anesthetized by MMB under a dark room. After anesthesia, retinal function was evaluated by ERG, as previously described in our paper [18]. Briefly, active electrodes were recorded in the contact lens and a reference electrode was placed in the mouth. ERG responses were obtained from both eyes of each animal. Scotopic responses were recorded with various stimuli. The amplitudes of a-wave were measured from the baseline to the lowest point of a-wave. The amplitudes of b-wave were measured from the lowest peak of a-wave to the highest peak of b-wave. During the procedure, all mice were kept in warm conditions using heat pads.

\subsection{Statistical Analysis}

Data analyses were performed using Prism 5 (GraphPad, San Diego, CA, USA). Statistically significant differences were calculated using a two-tailed Student's $t$-test or one-way ANOVA followed by a Bonferroni post hoc test. $p$-value of less than 0.05 was regarded as statistically significant.

\section{Results}

\subsection{Rice Bran or Vitamin B6 Shows Inhibitory Effects on HIF Activation in ARPE-19 Cells under a $\mathrm{CoCl}_{2}$-Induced Hypoxic Condition}

Food ingredients (with their expected components) were screened for inhibition of HIF activity (Figure 1A and Table A1). For the first gross screening, 661W cells (mouse immortalized cone photoreceptor cells with some features of retinal ganglion precursor-like cells) were utilized, as this cell line has been widely used as one of the in vitro cell models for ophthalmic drug development $[27,28]$ and a HIF-luciferase reporter stable cell line has already been established $[15,16]$. Screened samples were in order of strong inhibitory tendencies on HIF activation (Table A1). At the first line, the top 10 samples with strong inhibitory tendencies were selected among 202 samples on HIF activation under a $\mathrm{CoCl}_{2}$-induced hypoxic condition (number 1-10 in Table A1). After collecting the 10 samples (garcinia fruit extract with or without water solubility and lactoferrin and lactoferrin from milk were considered as one sample after the gross first screening), we carefully evaluated inhibitory effects of them again at the second screening with the same system. We found that only six samples consistently showed statistically significant inhibitory effects on $\mathrm{HIF}$ activation under a $\mathrm{CoCl}_{2}$-induced hypoxic condition (Table A2). 


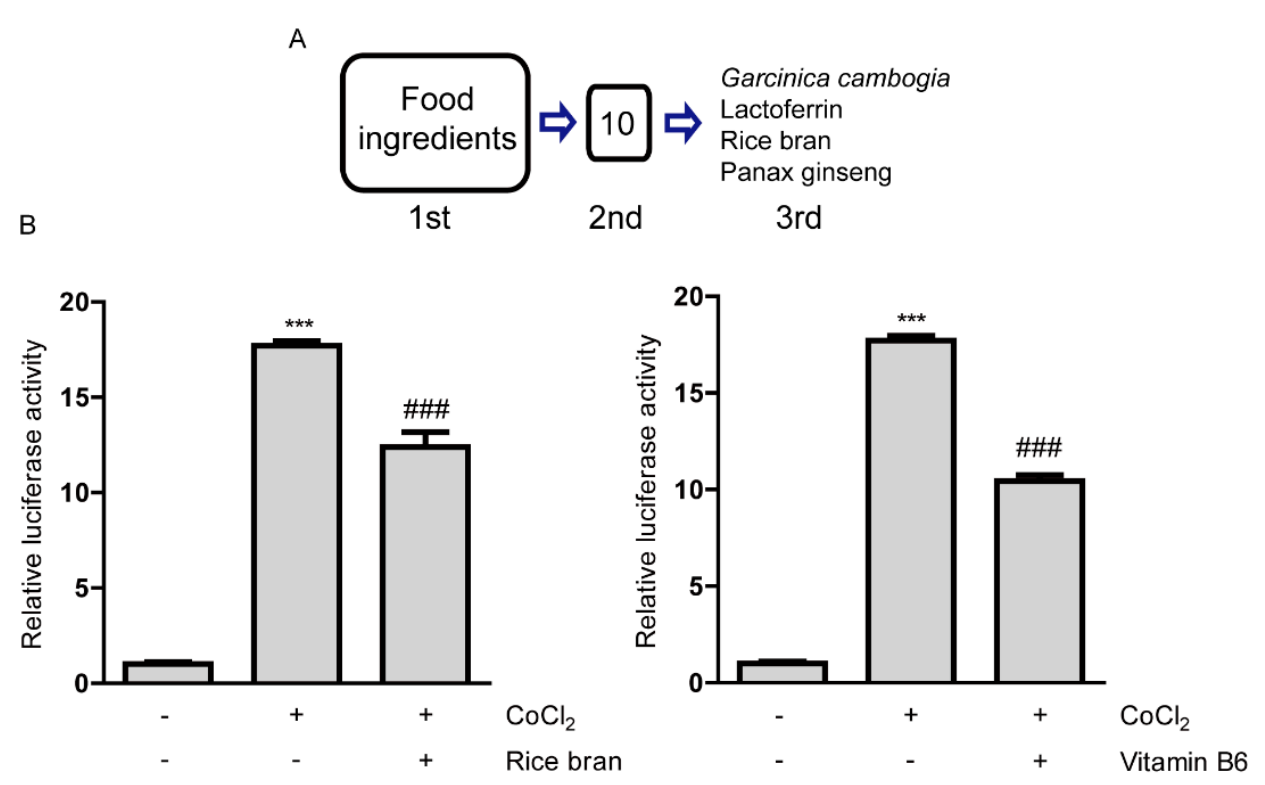

Figure 1. Inhibitory effects of rice bran and vitamin B6 on hypoxia-inducible factor (HIF) activity. (A) A process of drug screenings for HIF inhibitors. After the first screening, 10 samples were shown to be positive. After the second screening, four food ingredients (lactoferrin, rice bran, panax ginseng and Garcinia cambogia) with their expected 2 component compounds (hydroxycitric acid and vitamin B6) were selected as HIF inhibitors. (B) Quantitative analyses of HIF-reporter luciferase assay using ARPE-19 cells ( $n=3$ per group) showed that rice bran $(1 \mathrm{mg} / \mathrm{mL})$ and vitamin B6 $(1 \mathrm{mg} / \mathrm{mL})$ inhibited HIF activity induced by $200 \mu \mathrm{M} \mathrm{CoCl}_{2}$. ${ }^{* * *} p<0.001$, \#\#\# $p<0.001$, compared with no treatment and $200 \mu \mathrm{M}$ of $\mathrm{CoCl}_{2}$ treatment, respectively. Bar graphs were presented as mean with the \pm standard deviation. The data were analyzed using one-way ANOVA followed by a Bonferroni post hoc test. Solvents, rice bran: DMSO; vitamin B6: water.

We proceeded to the next final screening with these six samples. For the third final screening, we used ARPE-19 cells (human retinal pigmented epithelium cells) as this cell line also has been widely used for ophthalmic drug development $[27,29]$. In addition, this cell type, RPE cells, has been suggested as one of main pathological reasons for the development of CNV, finally leading to AMD [30-32]. Through the final screening, we found that six samples showed statistically significant HIF inhibitory effects (Figures 1B and A1 and [15,16]). Taken together, four food ingredients (with their expected two component compounds, hydroxycitric acid and vitamin B6) were positively selected as inhibitors of HIF activation, as listed 'Garcinia cambogia', 'lactoferrin', 'rice bran (Oryza sativa Linne, Gramineae, defatted)' and 'ginseng' (Figure 1A). Based on the screening results, we could demonstrate therapeutic effects of lactoferrin and Garcinia cambogia (and its abundant component hydroxycitric acid) via inhibition of HIF activation in murine models of CNV $[15,16]$.

Next, with the rest of the positively selected food ingredients (rice bran or ginseng) from the screenings, we further attempted to examine which components inside defatted rice bran or ginseng could help it to exert HIF inhibitory effects. While we could not find which components inside ginseng could help it to have HIF inhibitory effects, among the components contained in rice bran (Table A3), we have found that vitamin B6 showed a significant and the most robust HIF inhibitory effect (Figures 1B and A2). Taken together, in this current study, we mainly focused on unraveling potent effects of rice bran and vitamin $\mathrm{B} 6$ as novel HIF inhibitors. For further experiments under a $\mathrm{CoCl}_{2}$-induced hypoxic condition, we examined whether rice bran or vitamin B6 has cellular toxicity using MTT assay (Figure A3). Basically, cytotoxicity of them was not significantly detected although there was a decreasing tendency in mitochondrial activity in high-dose vitamin B6 $(1 \mathrm{mg} / \mathrm{mL})$-treated group. 
3.2. Rice Bran or Vitamin B6 Has Suppressive Effects on HIF Stabilization in ARPE-19 Cells under a CoCl2-Induced Hypoxic Condition

Suppressive effects of rice bran and vitamin B6 on HIF stabilization in protein levels were examined (Figure 2). HIF-1 $\alpha$ expression was stabilized in ARPE-19 cells $6 \mathrm{~h}$ after incubation of $200 \mu \mathrm{M}$ of $\mathrm{CoCl}_{2}$. Then, stabilized HIF-1 $\alpha$ expression was significantly reduced by rice bran and vitamin B6 treatments, respectively. On the other hand, in $661 \mathrm{~W}$ cells, there was no statistical difference by rice bran or vitamin B6 treatment in stabilized HIF-1 $\alpha$ expression $6 \mathrm{~h}$ after incubation of $200 \mu \mathrm{M}$ of $\mathrm{CoCl}_{2}$, (Figure A4). These results indicate that rice bran and vitamin B6 could have suppressive effects on HIF- $1 \alpha$ stabilization in RPE cells more than neuronal cells.
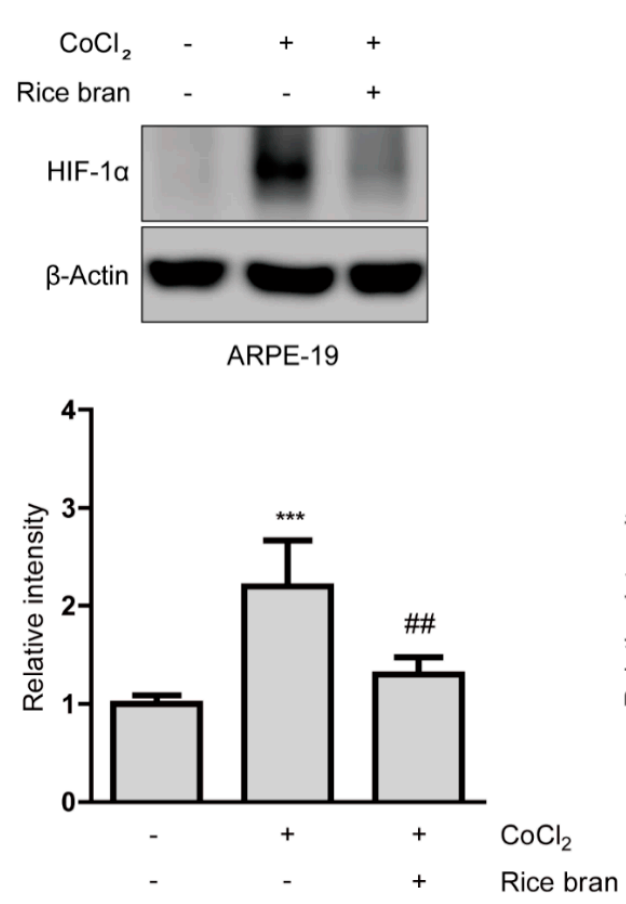
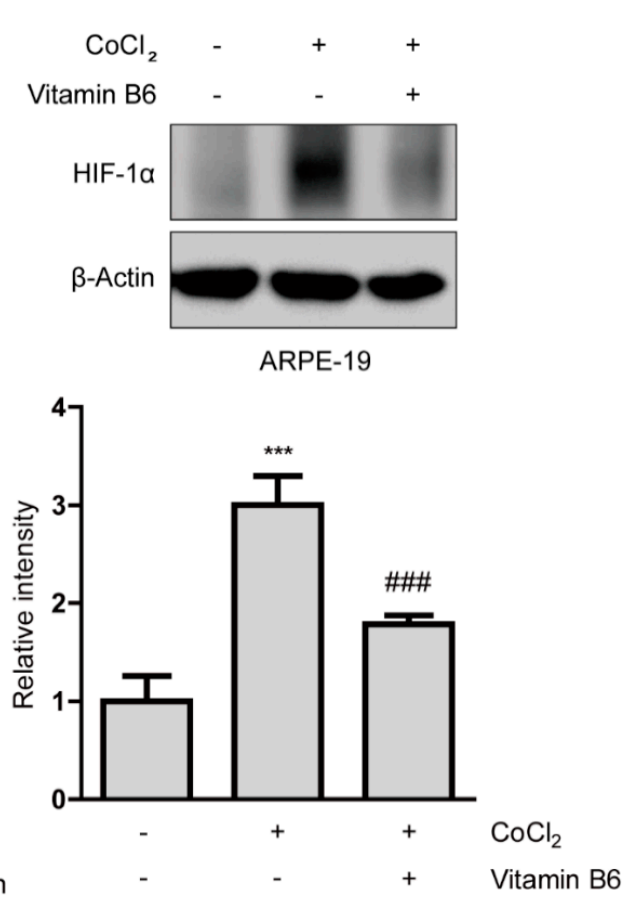

Figure 2. Suppressive effects of rice bran and vitamin B6 on HIF- $1 \alpha$ stabilization. Representative immunoblot images and quantitative analyses ( $n=4$ per group) for HIF- $1 \alpha$ and $\beta$-Actin showed that HIF- $1 \alpha$ was stabilized in ARPE-19 cells under a $\mathrm{CoCl}_{2}$-induced pseudo-hypoxic condition. Rice bran $(1 \mathrm{mg} / \mathrm{mL})$ and vitamin B6 $(1 \mathrm{mg} / \mathrm{mL})$ significantly decreased stabilized HIF-1 $\alpha$ expression. ${ }^{* * *} p<0.001$, compared with no treatment, \#\# $p<0.01$, \#\#\# $p<0.001$, compared with $\mathrm{CoCl}_{2}$ treatment. Bar graphs were presented as mean \pm standard deviation. The data were analyzed using one-way ANOVA followed by a Bonferroni post hoc test. Solvents, rice bran: DMSO; vitamin B6: water.

Next, we examined whether rice bran and vitamin B6 could act on another HIF expression (HIF-2 $\alpha$ ) in ARPE-19 cells under the same condition (Figure A5). We could not see a significant increase in HIF- $2 \alpha$ expression under a $\mathrm{CoCl}_{2}$-induced hypoxic condition, and rice bran and vitamin $\mathrm{B} 6$ did not change its expression. Taken together, it indicates that HIF- $1 \alpha$ (rather than HIF- $2 \alpha$ ) might be the major regulator in ARPE-19 cells under this hypoxic condition, which is in agreement with several previous reports using ARPE-19 cells [33-35].

\subsection{Rice Bran or Vitamin B6 Inhibits the HIF/VEGF Axis in ARPE-19 Cells under a CoCl2-Induced Hypoxic Condition}

Suppression on HIF-1 $\alpha$ stabilization in RPE cells could be followed by inhibition of DNA binding of stabilized HIF- $1 \alpha$, finally reducing induction of HIF target gene expressions, especially VEGF. Thus, we examined whether rice bran or vitamin B6 suppresses HIF downstream-target hypoxia-responsive gene expressions under a $\mathrm{CoCl}_{2}$-induced hypoxic condition (Figure 3). A total of $8 \mathrm{~h}$ after $200 \mu \mathrm{M}$ of $\mathrm{CoCl}_{2}$ incubation in ARPE-19 cells, downregulation of HIF-1 $\alpha$ mRNA expression was detected 
due to a negative feedback from the post translational HIF- $1 \alpha$ protein modification, which has been consistently seen in several previous papers $[15,16,19,36]$. $\mathrm{CoCl}_{2}$ induced upregulation of VEGF, BNIP3 and PDK1 mRNA expressions as results of HIF activation. Upregulated VEGF mRNA expression was significantly reduced by rice bran treatment. Although upregulated VEGF mRNA expression was not significantly reduced by vitamin B6 treatment, its expression showed a decreasing tendency. On the other hand, upregulated BNIP3 and PDK1 mRNA expressions were not significantly reduced by rice bran treatment although these expressions were significantly reduced by vitamin B6 treatment.
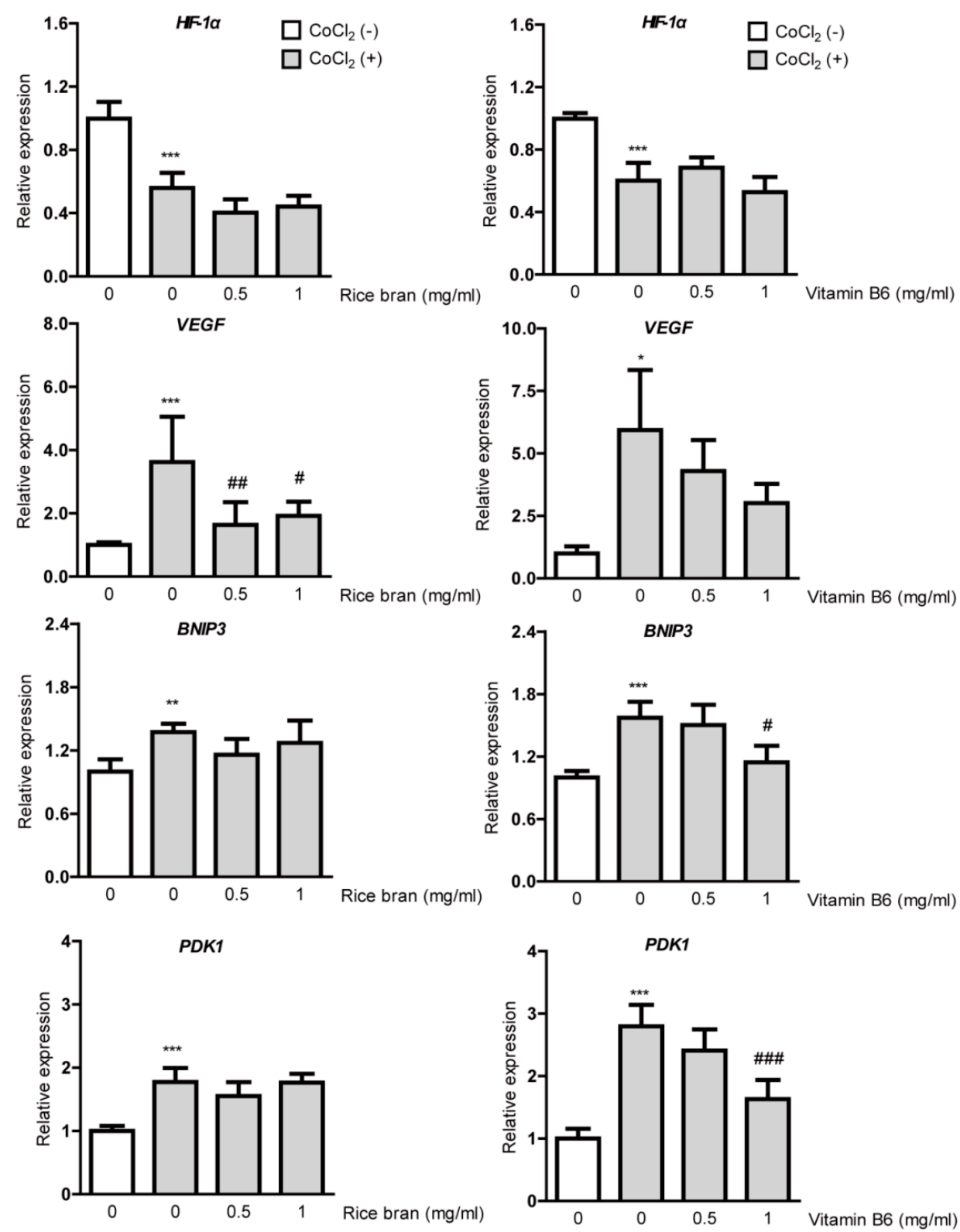

Figure 3. Suppression of hypoxia-responsive gene expressions by rice bran and vitamin B6. Quantitative analyses ( $n=4-6$ per group) showed significant changes in HIF-1 $\alpha, V E G F, B N I P 3$ and PDK1 mRNA expressions $8 \mathrm{~h}$ after incubation of $\mathrm{CoCl}_{2}$ in ARPE-19 cells. Upregulated VEGF mRNA expression was significantly reduced by rice bran treatment. There was a decreasing tendency of upregulated VEGF mRNA expression by vitamin B6 treatment. ${ }^{*} p<0.05,{ }^{* *} p<0.01,{ }^{* * *} p<0.001$, compared with no treatment, \# $p<0.05$, \#\# $p<0.01$, \#\#\# $p<0.001$, compared with $\mathrm{CoCl}_{2}$ treatment. Bar graphs were presented as mean with \pm standard deviation. The data were analyzed using one-way ANOVA followed by a Bonferroni post hoc test. Solvents, rice bran: DMSO; vitamin B6: water. 
3.4. Rice Bran or Vitamin B6 Administration Suppresses Retinal Neovascularization in a Murine Model of $C N V$

To assess therapeutic effects of rice bran and vitamin B6 on pathological neovascularization, a vitamin B6-deficient diet (AIN-93G, Oriental Yeast Co. Ltd., Tokyo, Japan) supplemented with vitamin B6 (9 or 35 mg/kg diet weight, DSM Nutritional Products Ltd., Kaiseraugst, Switzerland) or rice bran (defatted, $587.5 \mathrm{mg} / \mathrm{kg}$ diet weight, Oryza Oil \& Fat Chemical Co., Ltd., Ichinomiya, Japan) with vitamin B6 (1 mg/kg diet weight) was given to 4-weeks-old male mice for total 7 weeks (Figure 4A). The control group was provided with the basic diet (AIN-93G) which only contains $1 \mathrm{mg}$ of vitamin B6 in $1 \mathrm{~kg}$ of the diet. This amount of vitamin B6 is lower than that of normal diet commonly used for mouse studies; about 5-8 $\mathrm{mg}$ of vitamin B6 in $1 \mathrm{~kg}$ of diet, of which value could be considered as the roughly recommended amount for a daily life consumption.

A

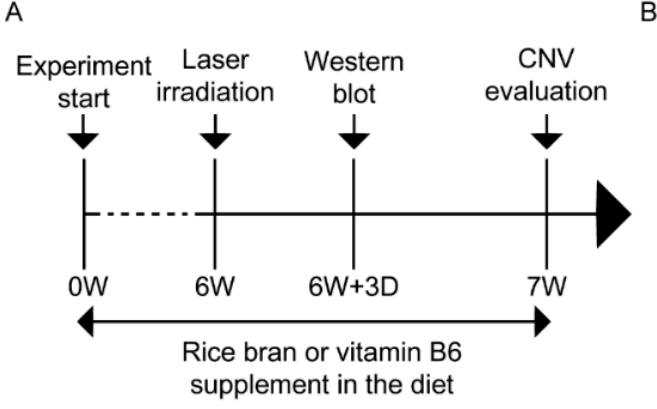

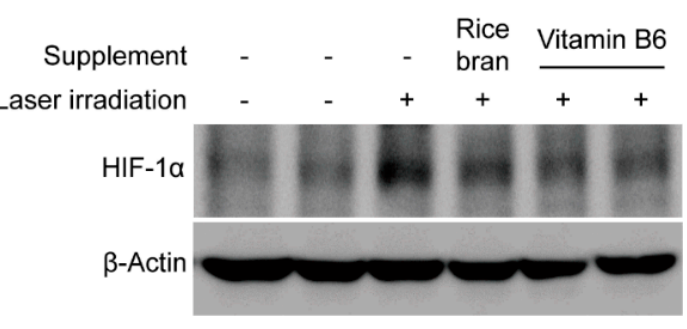

C
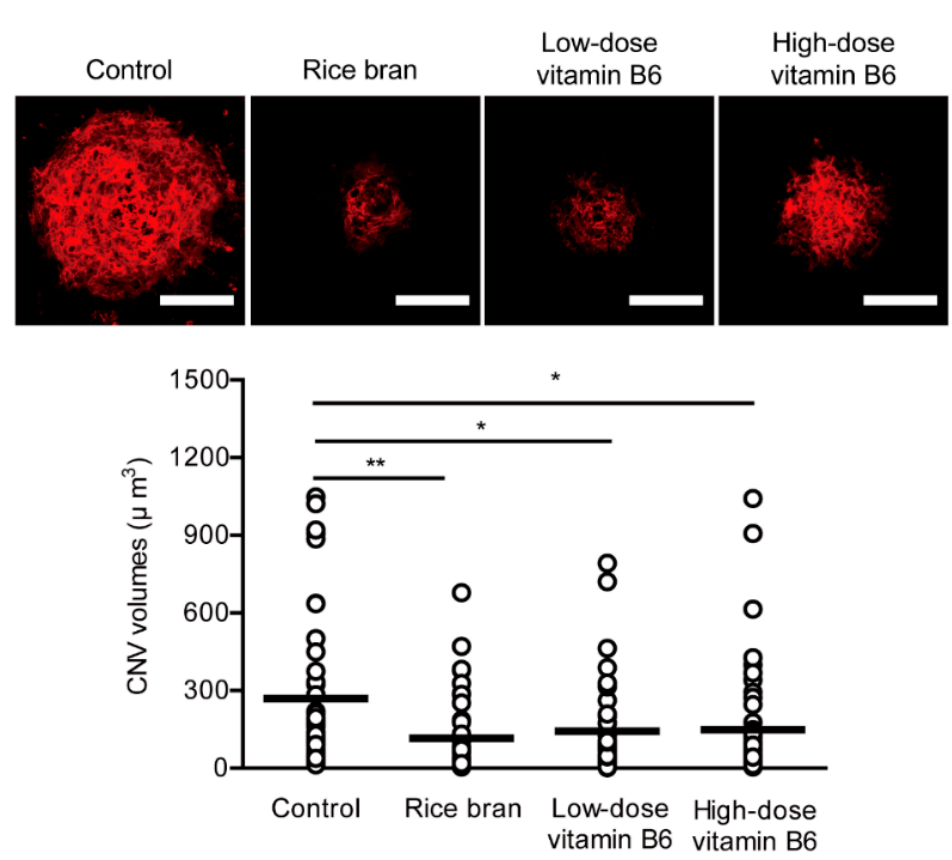

Figure 4. Suppression of neovascularization by rice bran and vitamin B6. (A) A schematic illustration demonstrates the murine choroidal neovascularization $(\mathrm{CNV})$ model procedure and administration of rice bran or vitamin B6 to mice. (B) An immunoblot image for HIF-1 $\alpha$ and $\beta$-Actin in the retina with or without the supplement of rice bran or vitamin B6, 3 days after the laser irradiation. (C) Representative images of $\mathrm{CNV}$ in the whole mount staining with isolectin B4 and quantitative analyses $(n=5-6$ per group, $n=42-49$ laser spots in the eyes per group) showed that the volume of CNV was significantly reduced by administration of rice bran $(587.5 \mathrm{mg} / \mathrm{kg}$ diet weight) and vitamin B6 (9 or $35 \mathrm{mg} / \mathrm{kg}$ diet weight), respectively. Scale bars, $100 \mu \mathrm{m} .{ }^{*} p<0.05,{ }^{* *} p<0.01$. Dot plot graphs were presented as mean. The data were analyzed using Student's $t$-test. 
After 3 days of irradiation by laser which was performed on week 6 after administration of diet supplemented with rice bran or vitamin B6, we could see stabilized HIF- $1 \alpha$ expression in the laser-irradiated retina and its expression was reduced by the rice bran- or vitamin B6-administered retina (Figure $4 \mathrm{~B}$ ). After 1 week of irradiation by laser, we quantified $\mathrm{CNV}$ volume as previously described [15,16]. A decreased volume of CNV was significantly observed in the rice bran- or vitamin B6-administered mice in comparison with that in the control mice, respectively (Figure 4C).

\subsection{Rice Bran or Vitamin B6 Administration Did Not Directly Affect Neuronal Dysfunction in a Murine} Model of LIR

To assess the therapeutic effects of the dietary supplement on protection in retinal function, we employed a murine LIR model of retinal degeneration. In this model, we could observe retinal dysfunction 1 week after the light exposure analyzed by ERG (Figure A6), which is in the basic agreement with previous observations $[26,37,38]$.

Next, we attempted to examine therapeutic effects of rice bran and vitamin B6 on direct retinal protection. A diet supplemented with rice bran or vitamin B6 was given to 5-weeks-old male mice for a total 8 weeks (Figure 5A). The control group was provided with a normal diet (which basically contains $1 \mathrm{mg} / \mathrm{kg}$ diet weight of vitamin B6) without the additional supplement. A total of 1 week after the light exposure which was performed on week 7 after administration of the diet supplemented with rice bran or vitamin $\mathrm{B} 6$, we found no significant change in the amplitudes of a- and b-waves among all of the groups except for the high-dose vitamin B6-administered group (Figure 5B,C). 
A

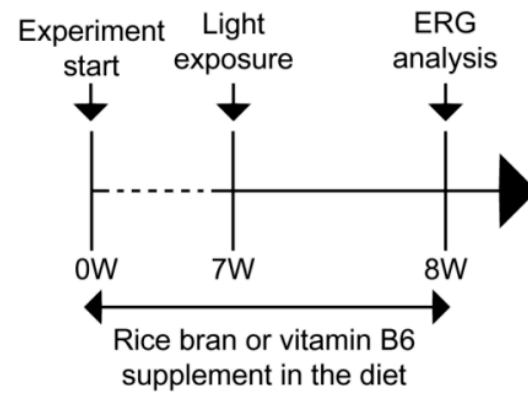

supplement in the diet

C

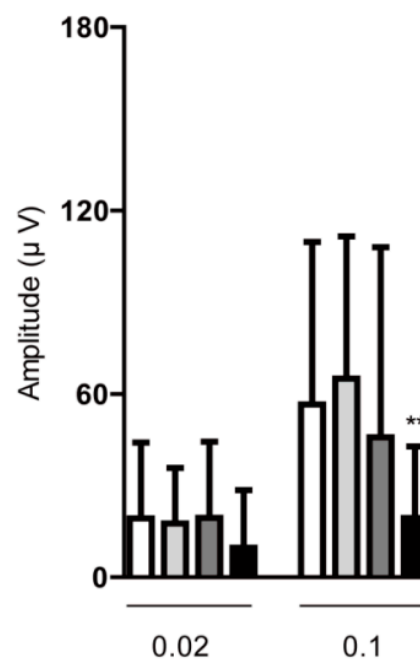

B

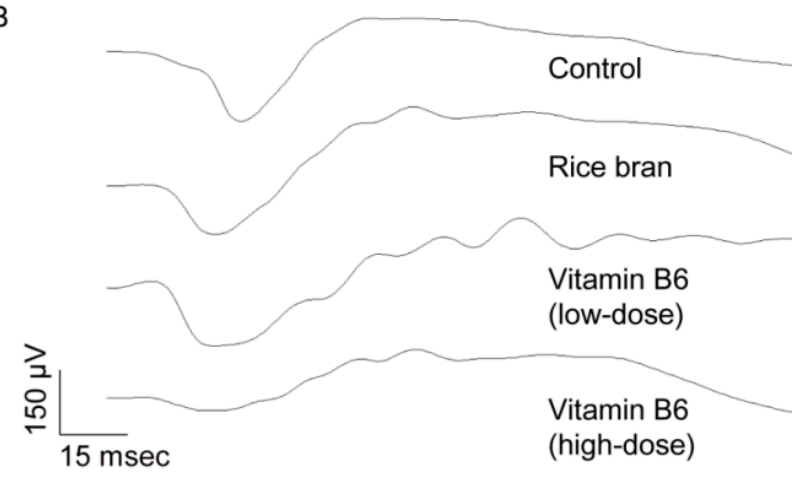

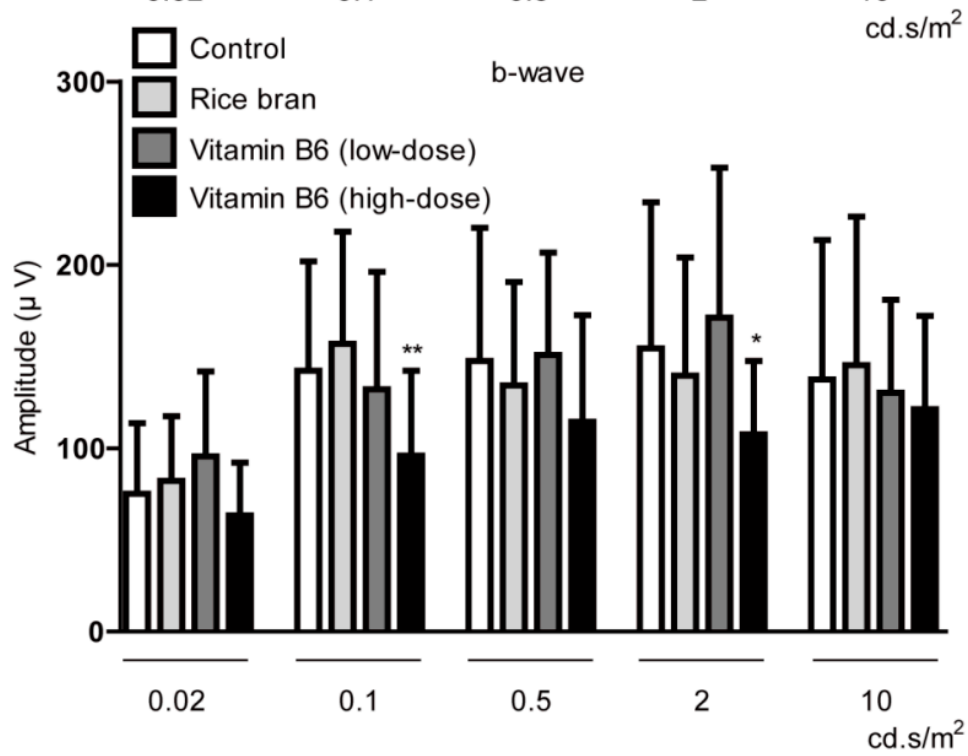

Figure 5. Direct retinal protection by rice bran and vitamin B6. (A) A schematic illustration demonstrates the murine light-induced retinopathy (LIR) model procedure and administration of rice bran or vitamin B6 to mice. (B,C) Representative waveforms of a- and b-waves $\left(2 \mathrm{cd.s} / \mathrm{m}^{2}\right)$ and quantitative analyses showed that rice bran $(587.5 \mathrm{mg} / \mathrm{kg}$ diet weight) or vitamin B6 (9 mg/kg diet weight) did not change the amplitudes of a-wave and b-wave in LIR mice ( $n=9-10$ per group, 18-20 eyeballs per group). There was a significant decrease in the amplitudes of a-wave and b-wave in high-dose vitamin B6 (35 mg/kg diet weight)-administered LIR mice. ${ }^{*} p<0.05,{ }^{* *} p<0.01$, compared with control. The data were analyzed using Student's $t$-test. 


\section{Discussion}

Rice bran is a hard-outer covering of rice grains and it is produced as a byproduct of milling for the production of refined rice [39]. In East Asia, people simply use rice bran to enrich some dishes and wish to increase their intake of dietary fiber as it contains vitamins, minerals, fatty acids, dietary fiber, and other sterols [39]. Rice bran has been traditionally thought to be a normal fiber material and considered enough for making cooking oil or feeding their livestock such as cattle or pigs. However, its high nutritional values received considerable attention after their therapeutic potentials were reported in various diseases [40]. In the current study, we found a new aspect of uses of rice bran as an HIF inhibitor and suggested vitamin B6 would be a working compound for this role among the components.

HIF plays a critical role in the maintenance of cellular homeostasis responded by alteration of oxygen status [8-10]. However, under pathological hypoxic conditions, HIF activation can cause devastating outcomes, in this case, retinal neovascularization [11]. Previously, we demonstrated that pharmacological intervention via administration of doxorubicin or topotecan [18], marine products [17], and a mushroom product [19] showed therapeutic effects on retinal neovascularization through inhibition of HIF activation and suppression of its downstream VEGF expression. In addition, we also demonstrated a significant reduction of $\mathrm{CNV}$ volume in RPE-specific Hif- $1 \alpha$-conditional knockout mice in comparison with that in control mice [15,41], which implies that genetic intervention of HIF is also a beneficial target against pathological hypoxic conditions in the eyes. In our current study, oral administration of rice bran or vitamin B6 as a diet supplement also showed similar therapeutic effects on retinal neovascularization. Taken together, we think that inhibition of HIF activation could have benefits for managing pathological ocular neovascularization.

The development of AMD involves complex pathological mechanisms. Above all, increasing evidence suggests that dysfunction of RPE is crucially involved in neovascular and atrophic forms of AMD [42]. RPE is a monolayer of polarized cells and lies underneath the retina intimately interacting with photoreceptor cells, of which communication is important for retinal homeostasis [43]. RPE controls the outer blood-retinal barrier via regulation of nutrient and oxygen delivery to the retina and clearance of metabolic waste from photoreceptor cells. RPE physiologically produces growth factors such as VEGF to support the retina and choriocapillaris [42,44,45]. Damages could occur to RPE over many years with ageing and increasing pathological stresses, which causes dysfunction of RPE and following pathological release of growth factors from RPE, especially VEGF [30,31]. This may be one of main pathological reasons for the development of CNV that finally leads to AMD [32]. In our study, upregulated VEGF mRNA expression in APRE-19 cells under a $\mathrm{CoCl}_{2}$-induced hypoxic condition was reduced by rice bran treatment. However, more data are required to unravel the in vivo mode of action regarding the reduction in VEGF levels in the eye by administration of rice bran or vitamin B6. This will be further studied. Moreover, $\mathrm{CNV}$ is one of the complex tissues in the eye composed of vascular components including endothelial cells, vascular smooth muscle cells, and pericytes, and extravascular cells such as inflammatory cells, fibroblasts, glial cells, and RPE cells [46-48]. Recently, endothelial cells, vascular smooth muscle cells, macrophages, and RPE cells have been suggested to be main cell types of $\mathrm{CNV}$ formation [46-48]. It is still hard to tell which cells exactly give the most contribution of CNV formation. Therefore, we think that more comprehensive studies regarding the relationship of VEGF-producing cell types with contribution of CNV formation may be needed for a better understanding of pathological mechanisms for ocular neovascularization. Nonetheless, based on what we have found so far, we suggest that a strategy to control RPE using rice bran or vitamin B6 might be applicable for AMD therapy.

Secondly, we examined a direct therapeutic role of rice bran (along with vitamin B6) in the retina. However, we could not see the positive effect. Instead, high-dose vitamin B6 administration caused retinal damages, which implies an excessive amount of vitamin $\mathrm{B} 6$ may not be suitable for retinal function. Furthermore, stabilized HIF- $1 \alpha$ expression in neuronal cells under a $\mathrm{CoCl}_{2}$-induced hypoxic condition was less affected by rice bran and vitamin B6. Although more studies are required, rice 
bran may directly work on RPE cells under pathological conditions in the eye rather than to work on neuronal cells.

Hypoxia-responsive genes other than VEGF were also examined in our study. Interestingly, BNIP3 and PDK1 expressions were not dramatically reduced by rice bran treatment while VEGF expression showed the expected result. Furthermore, BNIP3 and PDK1 expressions were significantly reduced by vitamin $\mathrm{B} 6$ treatment. This might be explained by the fact that rice bran contains several components other than vitamin B6 [39], which could induce other unknown signaling pathways to hinder inhibition of hypoxia-responsive gene induction under a $\mathrm{CoCl}_{2}$-induced hypoxic condition. More comprehensive studies regarding unknown effects of each component in rice bran may be further needed for a better understanding of pathological mechanisms for ocular neovascularization.

To date, effective treatments for pathological retinal neovascularization contain intravitreal injection of anti-VEGF drugs as well as laser photocoagulation, topical injection of corticosteroids, and vitreoretinal surgery [4,49].Chronic anti-VEGF therapies may induce photoreceptor cell atrophy [50] as it could abrupt normal physiological roles of VEGF for retinal function [51]. In addition, these treatments are very of high cost and even invasive to the eye, which is not patient-friendly [52,53]. In our current study, we targeted pathological HIF activation using rice bran to reduce HIF-induced pathological VEGF expression. In addition, edible rice bran is cost-effective and noninvasive to patients as it is always produced as a byproduct of milling for the production of rice [39] and possesses its beneficial features of good patient compliance and fear or pain avoidance [54].

\section{Conclusions}

In conclusion, we screened various types of food ingredients as prospective HIF inhibitors and demonstrated that rice bran and its component vitamin B6 possess HIF inhibitory effects. Furthermore, they showed their suppressive effects on pathological retinal neovascularization in a murine CNV model. Rice bran or vitamin B6 dietary supplement could be useful as stand-alone therapies or as adjuvants to anti-VEGF therapies for neovascularization in ocular diseases.

\section{Patents}

The data of the current research have applied for a patent (application number: 2019-038043).

Author Contributions: T.K. provided technical and funding assistance. M.I. and T.K. designed the study. M.I., D.L., A.S. and Y.M. performed the experiments. M.I., D.L. and A.S. analyzed the results. D.L. summarized all of the results and wrote the manuscript. T.K. and K.T. reviewed and edited the manuscript. All authors have read and agreed to the published version of the manuscript.

Funding: This work was supported by Grants-in-Aid for Scientific Research (KAKENHI) (18K09424 to Toshihide Kurihara) from the Ministry of Education, Culture, Sports, Science and Technology (MEXT).

Acknowledgments: We thank ROHTO Pharmaceutical Co. Ltd. for sharing food ingredients and their critical discussions. We also thank our lab members, S. Ikeda, Y. Katada, H. Jeong, K. Kurosaki, and A. Kawabata for their critical discussions.

Conflicts of Interest: The authors declare no conflict of interest except for the patent issue. 


\section{Appendix A}

Table A1. First screening of HIF inhibitors.

\begin{tabular}{|c|c|c|}
\hline Number & Name & Fold Change \\
\hline 1 & Hydroxycitric acid & 0.24 \\
\hline \multirow[t]{2}{*}{2} & Garcinia fruit extract & 0.30 \\
\hline & (hydroxycitric acid $\geq 50 \%$, calcium $\geq 18 \%$ ) & \\
\hline 3 & $\begin{array}{l}\text { Garcinia fruit extract, water soluble } \\
\text { (hydroxycitric acid } \geq 60 \% \text { ) }\end{array}$ & 0.40 \\
\hline 4 & $\begin{array}{c}\text { Ginkgo biloba extract A } \\
\text { (flavonoid } \geq 24 \% \text {, terpene lactones } \geq 6 \% \text { ) }\end{array}$ & 0.46 \\
\hline 5 & Panax ginseng & 0.48 \\
\hline 6 & Lactoferrin from milk & 0.49 \\
\hline 7 & Rice bran, defatted & 0.51 \\
\hline 8 & Lactoferrin & 0.57 \\
\hline 9 & Vitamin B6 (pyridoxine hydrochloride) & 0.58 \\
\hline 10 & Thiamine mononitrate & 0.63 \\
\hline 11 & Tilia cordata flower extract A & 0.64 \\
\hline 12 & $\begin{array}{c}\text { Garcinia peel extract } \\
\text { (hydroxy citric acid } \geq 60 \% \text { ) }\end{array}$ & 0.64 \\
\hline 13 & Enterococcus faecalis B & 0.65 \\
\hline 14 & $\begin{array}{l}\text { Summer pumpkin seed extract } \\
\text { (fatty acid } \geq 85 \% \text {, total sterol } \geq 0.3 \% \text { ) }\end{array}$ & 0.66 \\
\hline 15 & $\begin{array}{l}\text { Grape pomace extract } \mathrm{A} \\
\text { (oleanolic acid } \geq 2.0 \% \text { ) }\end{array}$ & 0.68 \\
\hline 16 & $\begin{array}{l}\text { Maqui berry fruit extract } \\
\text { (anthocyanins } \geq 35 \% \text {, delphinidins } \geq 20 \% \text { ) }\end{array}$ & 0.68 \\
\hline 17 & Dextrin & 0.69 \\
\hline 18 & $\begin{array}{c}\text { Strawberry seed extract } \\
\text { (polyphenol } \geq 2.0 \% \text {, tiliroside } \geq 0.5 \% \text { ) }\end{array}$ & 0.71 \\
\hline 19 & Ginsenoside Rf & 0.73 \\
\hline 20 & Petasites japonicus extract & 0.74 \\
\hline 21 & Vitamin A palmitate & 0.74 \\
\hline \multirow[t]{2}{*}{22} & Tomato extract A & 0.75 \\
\hline & $\begin{array}{l}\text { (lycopene } \geq 15 \%, \text { tocopherol } \geq 1.5 \%, \\
\text { phytoene phytofluene } \geq 1.0 \%, \beta \text {-carotene } \geq 0.2 \% \text { ) }\end{array}$ & \\
\hline 23 & Panax notoginseng root extract & 0.76 \\
\hline 24 & Sasa veitchii leaf extract & 0.77 \\
\hline \multirow[t]{2}{*}{25} & Cockscomb extract & 0.80 \\
\hline & (hyaluronic acid $\geq 5 \%$, hydroxyproline $\geq 8 \%$ ) & \\
\hline 26 & $\begin{array}{l}\text { Red dragon fruit extract } \\
\text { (betacyanin } \geq 0.05 \% \text { ) }\end{array}$ & 0.80 \\
\hline 27 & Tilia cordata flower extract B & 0.85 \\
\hline \multirow[t]{2}{*}{28} & Seaberry fruit extract & 0.85 \\
\hline & (triterpenes $\geq 0.2 \%$, isorhamnetin rhamnoside $\geq 0.2 \%$ ) & \\
\hline 29 & Cyanocobalamin & 0.88 \\
\hline 30 & Hovenia dulcis extract & 0.90 \\
\hline 31 & Polyphenol & 0.91 \\
\hline 32 & Siraitia grosvenorii extract & 0.91 \\
\hline 33 & Peptide formulation derived from dairy protein & 0.92 \\
\hline 34 & Phosphoryl oligosaccharides of calcium & 0.94 \\
\hline 35 & Tilia cordata flower extract $C$ & 0.95 \\
\hline 36 & L-Carnitine & 0.96 \\
\hline 37 & $\begin{array}{l}\text { Myrciaria dubia fruit extract } \\
\quad \text { (citric acid } \geq 1 \% \text { ) }\end{array}$ & 0.97 \\
\hline 38 & Monostroma nitidum extract & 0.97 \\
\hline
\end{tabular}


Table A1. Cont.

\begin{tabular}{|c|c|c|}
\hline Number & Name & Fold Change \\
\hline 39 & Aspalathus linearis extract B & 1.00 \\
\hline 40 & Parsley extract & 1.02 \\
\hline 41 & Honey & 1.03 \\
\hline 42 & Panax ginseng root extract $\mathrm{H}$ & 1.03 \\
\hline 43 & Niacinamide & 1.04 \\
\hline 44 & $\begin{array}{c}\text { Maca extract } \\
\text { (benzyl glucosinolate } \geq 2.4 \% \text { ) }\end{array}$ & 1.04 \\
\hline 45 & $\begin{array}{l}\text { Broccoli sprout extract B } \\
\text { (glucoraphanin } \geq 3 \%)\end{array}$ & 1.05 \\
\hline 46 & Peptide formulation derived from milk protein A & 1.05 \\
\hline 47 & $\begin{array}{l}\text { Hydrolyzed rice bran extract } \\
\text { (peptide } \geq 60 \% \text { ) }\end{array}$ & 1.05 \\
\hline 48 & Polysaccharide from yeast & 1.06 \\
\hline 49 & Branched chain amino acids & 1.06 \\
\hline 50 & Chlorogenic acid & 1.06 \\
\hline 51 & Ginsenoside $\mathrm{Rb} 1$ & 1.07 \\
\hline 52 & Panax ginseng root extract $C$ & 1.08 \\
\hline 53 & Chamomile flower extract & 1.09 \\
\hline 54 & Salmon milt extract & 1.09 \\
\hline 55 & Kidney beans extract B & 1.10 \\
\hline 56 & $\begin{array}{l}\text { Acerola fruit extract } A \\
\quad \text { (vitamin } C \geq 30 \%)\end{array}$ & 1.12 \\
\hline 57 & $\begin{array}{l}\text { Acerola fruit extract } B \\
\text { (vitamin } C \geq 20 \%)\end{array}$ & 1.12 \\
\hline 58 & Ginkgo biloba extract B & 1.14 \\
\hline 59 & $\begin{array}{l}\text { Eleutherococcus senticosus extract } \\
\text { (saponin } \geq 2 \% \text { ) }\end{array}$ & 1.14 \\
\hline 60 & Vitamin $\mathrm{K} 2$ & 1.16 \\
\hline 61 & $\begin{array}{c}\text { Astragalus complanatus extract } \\
\text { (flavonoid } \geq 5 \% \text { ) }\end{array}$ & 1.17 \\
\hline 62 & Peptide formulation derived from casein A & 1.20 \\
\hline 63 & Selenium & 1.22 \\
\hline 64 & Rosa canina fruit extract & 1.23 \\
\hline 65 & Perilla leaf extract B & 1.26 \\
\hline 66 & Mugwort leaf extract & 1.26 \\
\hline 67 & Milk protein & 1.27 \\
\hline 68 & $\begin{array}{l}\text { Evening primrose oil } \\
\text { (cis-gamma-linolenic acid and linoleic acid 76\%) }\end{array}$ & 1.27 \\
\hline 69 & Glucosyl hesperidin A (hesperidin $\geq 70 \%$ ) & 1.27 \\
\hline 70 & Japanese hawthorn fruit extract & 1.28 \\
\hline 71 & Chinese chive extract (S-allyl-L-cysteine $\geq 0.1 \%$ ) & 1.29 \\
\hline 72 & Enterococcus faecalis A & 1.30 \\
\hline 73 & Coenzyme Q10 & 1.30 \\
\hline 74 & Peptide formulation derived from casein B & 1.32 \\
\hline 75 & $\beta$-Carotene & 1.35 \\
\hline 76 & Peptide formulation derived from milk protein B & 1.37 \\
\hline 77 & Moringa leaf extract & 1.38 \\
\hline 78 & Ganoderma lucidum extract & 1.39 \\
\hline 79 & Rice germ extract $\mathrm{A}$ (polyamine $\geq 0.2 \%$ ) & 1.41 \\
\hline 80 & Boswellic acid & 1.41 \\
\hline 81 & Tocopherol & 1.43 \\
\hline 82 & $\begin{array}{c}\text { Kiwi fruit seed extract } \\
\text { (polyphenol } \geq 2 \% \text {, quercitrin } \geq 0.05 \mathrm{mg} / 1 \mathrm{~g} \text { ) }\end{array}$ & 1.44 \\
\hline 83 & Glucosyl hesperidin B & 1.45 \\
\hline 84 & Calcium & 1.46 \\
\hline
\end{tabular}


Table A1. Cont.

\begin{tabular}{|c|c|c|}
\hline Number & Name & Fold Change \\
\hline 85 & $\begin{array}{c}\text { Paprika extract B } \\
\text { (xanthophyll } \geq 27 \mathrm{mg} / \mathrm{g}, \text { capsanthin } \geq 15 \mathrm{mg} / \mathrm{g} \text {, } \\
\beta \text {-cryptoxanthin } \geq 1.5 \mathrm{mg} / \mathrm{g} \text { ) }\end{array}$ & 1.47 \\
\hline 86 & Licorice extract A & 1.47 \\
\hline 87 & Coprinus comatus extract & 1.49 \\
\hline 88 & Alpinia speciosa leaf extract & 1.49 \\
\hline 89 & Pomegranate extract (ellagic acid 80\%) & 1.54 \\
\hline 90 & Grifola frondosa mushroom extract & 1.54 \\
\hline 91 & Olive fruit extract B (maslinic acid $\geq 10 \%$ ) & 1.55 \\
\hline 92 & Pearl barley seed extract & 1.55 \\
\hline 93 & Saffron extract & 1.57 \\
\hline 94 & Perilla frutescens leaf powder & 1.57 \\
\hline 95 & Soybean protein & 1.57 \\
\hline 96 & $\begin{array}{c}\text { Cherry blossom flower extract } \\
\text { (caffeoyl glucose } \geq 2.0 \% \text {, quercetin glucoside } \geq 0.05 \% \text { ) }\end{array}$ & 1.58 \\
\hline 97 & Royal jelly (decenoic acid 1.6-1.8\%) & 1.71 \\
\hline 98 & Soybean extract & 1.77 \\
\hline 99 & Seaweed mineral & 1.78 \\
\hline 100 & Ginsenoside, compound $\mathrm{K}$ & 1.78 \\
\hline 101 & Lactulos & 1.78 \\
\hline 102 & Brewers' yeast extract & 1.78 \\
\hline 103 & Panax ginseng root extract D & 1.81 \\
\hline 104 & Golden oyster mushroom extract & 1.88 \\
\hline 105 & Barley powder ( $\beta$-glucan 15\%) & 1.88 \\
\hline 106 & Tamarind extract & 1.95 \\
\hline 107 & Isatis tinctoria extract & 2.05 \\
\hline 108 & Indian long pepper fruit extract & 2.12 \\
\hline 109 & Gardenia fruit extract B & 2.15 \\
\hline 110 & Amla fruit extract (gallotannnin $\geq 15 \%$ ) & 2.17 \\
\hline 111 & Arctium lappa ferment extract & 2.19 \\
\hline 112 & Arctium lappa root extract & 2.24 \\
\hline 113 & Broccoli sprout extract A (sulforaphane $\geq 2 \%$ ) & 2.24 \\
\hline 114 & Euphrasia rostkoviana extract & 2.27 \\
\hline 115 & Phellinus linteus extract & 2.27 \\
\hline 116 & Chinese wolfberry fruit extract & 2.30 \\
\hline 117 & Rosemary leaf extract & 2.31 \\
\hline 118 & $\begin{array}{c}\text { Black rice seed extract } \\
\text { (polyphenol } \geq 15 \% \text {, anthocyanidin } \geq 5 \% \text { ) }\end{array}$ & 2.31 \\
\hline 119 & Plant oil & 2.34 \\
\hline 120 & Zingiber purpureum extract & 2.39 \\
\hline 121 & Sweet clover extract & 2.40 \\
\hline 122 & $\begin{array}{c}\text { Grape bud extract } \\
\text { (resveratrol } \geq 20 \% \text {, trans-resveratorol } \geq 5 \%, \varepsilon \text {-viniferin } \geq 5 \% \text { ) }\end{array}$ & 2.41 \\
\hline 123 & $\begin{array}{l}\text { Cocoa seed extract } \\
\text { (theobromine } \geq 10 \% \text {, polyphenol } \geq 20 \%)\end{array}$ & 2.43 \\
\hline 124 & $\begin{array}{l}\text { Bilberry fruit extract } \mathrm{A} \\
\text { (anthocyanosides } \geq 85 \% \text { ) }\end{array}$ & 2.44 \\
\hline 125 & $\begin{array}{l}\text { Linseed extract } \\
\text { (secoisolariciresinol diglucoside } \geq 40 \% \text { ) }\end{array}$ & 2.80 \\
\hline 126 & Calcium ascorbate & 3.02 \\
\hline 127 & Mulberry leaf extract (1-deoxynojirimycin $\geq 1 \%$ ) & 3.10 \\
\hline 128 & $\begin{array}{l}\text { Siberian ginseng root extract } \\
\text { (eleutherosides } \mathrm{B}+\mathrm{E} \geq 0.9 \%)\end{array}$ & 3.11 \\
\hline 129 & Ginger extract B & 3.30 \\
\hline 130 & Siberian larch extract (dihydroquercetin $\geq 88 \%$ ) & 3.40 \\
\hline 131 & Coconut oil & 3.43 \\
\hline
\end{tabular}


Table A1. Cont.

\begin{tabular}{|c|c|c|}
\hline Number & Name & Fold Change \\
\hline 132 & Marigold flower extract A (lutein $\geq 20 \%$, zeaxanthin $1-2 \%$ ) & 3.48 \\
\hline 133 & Lemon verbena extract (acteoside and isoacteoside $\geq 9-11 \%$ ) & 3.71 \\
\hline 134 & Cyanidin 3-glucoside & 3.76 \\
\hline 135 & Sichuan pepper peel extract & 3.84 \\
\hline 136 & Pyrroloquinoline quinone & 3.87 \\
\hline 137 & Olive leaf extract A (oleanolic acid $\geq 55 \%$ ) & 4.05 \\
\hline 138 & Gymnema sylvestre extract B (gymnemic acid $\geq 25 \%$ ) & 4.09 \\
\hline 139 & Psidium guajava leaf extract (tannin $\geq 18 \%$ ) & 4.11 \\
\hline 140 & Geranylgeraniol & 4.24 \\
\hline 141 & Lemon balm leaf extract & 4.46 \\
\hline 142 & Olive leaf extract B & 4.48 \\
\hline 143 & Riboflavin & 4.57 \\
\hline 144 & $\begin{array}{c}\text { Kaempferia parviflora extract } \\
\text { (5,7-dimethoxyflavone } \geq 4 \% \text {, polymethoxyflavonoid } \geq 15 \%)\end{array}$ & 4.65 \\
\hline 145 & $\begin{array}{l}\text { Curcuma extract B } \\
\text { (curcuminoid 19-22\%, curcumin } \geq 13 \% \text { ) }\end{array}$ & 4.69 \\
\hline 146 & $\begin{array}{l}\text { Coffee seed extract } \\
\text { (chlorogenic acid } \geq 24.0 \%)\end{array}$ & 4.97 \\
\hline 147 & Oleanolic acid & 5.00 \\
\hline 148 & Cranberry extract $C$ (proanthocyanidins $\geq 50 \%$ ) & 5.20 \\
\hline 149 & Panax ginseng root extract $\mathrm{E}$ (compound $\mathrm{K} \geq 5 \mathrm{mg} / \mathrm{g}$ ) & 5.21 \\
\hline 150 & $\begin{array}{c}\text { Ginger extract } A \\
\text { (gingerols } \geq 15 \%, 6,8,10 \text {-gingerols } \geq 12 \% \text {, shogaol } \geq 3 \% \text { ) }\end{array}$ & 5.25 \\
\hline 151 & Japanese horseradish extract & 5.29 \\
\hline 152 & $\begin{array}{l}\text { Curcuma extract A } \\
\text { (curcuminoid complex } \geq 95 \% \text {, curcumin } \geq 65 \% \text { ) }\end{array}$ & 5.37 \\
\hline 153 & Melinjo seed extract (resveratrol $\geq 20 \%$ ) & 5.40 \\
\hline 154 & $\begin{array}{l}\text { Grape marc extract } \\
\text { (polyphenol } \geq 92 \% \text {, proanthocyanidin } \geq 15 \%, \\
\text { anthocyanin } \geq 2 \% \text {, t-resveratrol } \geq 2500 \mathrm{ppm} \text { ) }\end{array}$ & 5.42 \\
\hline 155 & Ginsenoside C-K (compound $\mathrm{K} \geq 98 \%$ ) & 5.51 \\
\hline 156 & Ginkgo biloba extract $C$ & 5.53 \\
\hline 157 & Ginsenoside $\operatorname{Rg} 3$ & 5.64 \\
\hline 158 & Laurel leaf extract (deacetyl laurenobiolide $\geq 1 \%$ ) & 5.88 \\
\hline 159 & Aspalathus linearis extract A (aspalathin $\geq 20 \%$ ) & 5.88 \\
\hline 160 & Bacopa monniera extract & 5.95 \\
\hline 161 & Perilla seed extract & 6.24 \\
\hline 162 & Panax ginseng root extract $\mathrm{K}$ & 6.30 \\
\hline 163 & Gymnema sylvestre extract A & 6.31 \\
\hline 164 & Cat's claw extract & 6.37 \\
\hline 165 & Panax ginseng root extract $\mathrm{F}$ & 6.45 \\
\hline 166 & Black chokeberry fruit extract & 6.49 \\
\hline 167 & American panax quinquefolius root extract $\mathrm{A}$ & 6.91 \\
\hline 168 & Coleus forskohlii extract & 6.96 \\
\hline 169 & Panax ginseng root extract $\mathrm{L}$ & 7.12 \\
\hline 170 & Mangosteen peel extract (maclurin glycosides $\geq 0.03 \%$ ) & 7.22 \\
\hline 171 & Docosahexaenoic acid & 7.22 \\
\hline 172 & Mallotus japonicus peel extract (bergenin $\geq 12 \%$ ) & 7.61 \\
\hline 173 & Fucoxanthin B & 7.77 \\
\hline 174 & Grape seed extract (polyphenol $\geq 95 \%$, proanthocyanidin $\geq 40 \%$ ) & 7.83 \\
\hline 175 & Evening primrose seed extract & 7.94 \\
\hline 176 & Citrus extract & 7.96 \\
\hline 177 & Olive fruit extract $\mathrm{A}$ & 7.96 \\
\hline 178 & Andrographis paniculata extract & 8.14 \\
\hline 179 & Cranberry extract B & 8.43 \\
\hline 180 & Banaba leaf extract & 8.67 \\
\hline
\end{tabular}


Table A1. Cont.

\begin{tabular}{|c|c|c|}
\hline Number & Name & Fold Change \\
\hline 181 & Peanut seed coat extract & 8.97 \\
\hline 182 & Glucosylceramide & 9.16 \\
\hline 183 & Pomegranate fruit extract & 9.86 \\
\hline 184 & Artichoke leaf extract & 10.09 \\
\hline 185 & Eicosapentaenoic acid & 10.23 \\
\hline 186 & Propolis extract A & 10.44 \\
\hline 187 & Black soybean extract & 10.64 \\
\hline 188 & Licorice extract B (glycyrrhizinic acid $\geq 20 \%$ ) & 10.71 \\
\hline 189 & Propolis extract B & 10.82 \\
\hline 190 & $\begin{array}{l}\text { Bilberry fruit extract B } \\
\text { (anthocyanidin } \geq 25 \% \text {, anthocyanin } \geq 36 \% \text { ) }\end{array}$ & 11.44 \\
\hline 191 & $\begin{array}{c}\text { Paprika extract A } \\
\text { (xanthophyll } \geq 9 \mathrm{mg} / \mathrm{g} \text {, capsanthin } \geq 5 \mathrm{mg} / \mathrm{g} \text {, } \\
\beta \text {-cryptoxanthin } \geq 0.5 \mathrm{mg} / \mathrm{g} \text { ) }\end{array}$ & 11.71 \\
\hline 192 & Quercus salicina leaf extract (tannins $\geq 18 \%$ ) & 12.00 \\
\hline 193 & Hesperetin & 12.33 \\
\hline 194 & $\begin{array}{l}\text { Pterocarpus marsupium extract } \\
\text { (pterostibene } \geq 5 \% \text { ) }\end{array}$ & 12.65 \\
\hline 195 & Tomato extract B (lycopene $\geq 10 \%)$ & 13.15 \\
\hline 196 & Cranberry extract D (proanthocyanidins $27-33 \%$ ) & 13.37 \\
\hline 197 & Fucoxanthin A & 13.94 \\
\hline 198 & $\begin{array}{c}\text { Grape stem extract } \\
\text { (resveratrol } \geq 3.5 \% \text {, oligo-stilbenes } \geq 1 \%, \varepsilon \text {-viniferin } \geq 0.8 \%)\end{array}$ & 14.74 \\
\hline 199 & Salacia reticulata extract (mangiferin $\geq 1 \%$, triterpenoids $\geq 20 \%$ ) & 15.58 \\
\hline 200 & Apocynum venetum extract (hyperoside and isoquercitin $\geq 4 \%$ ) & 19.67 \\
\hline 201 & Green tea extract & 20.65 \\
\hline 202 & Gardenia fruit extract $\mathrm{A}$ (crocetin $\geq 75 \%$ ) & 27.55 \\
\hline
\end{tabular}

Fold changes of HIF activity by the ingredients were compared with the value of $\mathrm{CoCl}_{2}$-induced $\mathrm{HIF}$ activity in $661 \mathrm{~W}$ cells $(n=1$ per sample).

\section{Appendix B}

Table A2. Second screening of HIF inhibitors.

\begin{tabular}{cccc}
\hline Number & Name & Fold Change + SD & $p$-Value \\
\hline 1 & Garcinia fruit extract & $0.38 \pm 0.12$ & $0.003^{* *}$ \\
2 & Hydroxycitric acid & $0.44 \pm 0.20$ & $0.035^{*}$ \\
3 & Rice bran, defatted & $0.58 \pm 0.05$ & $0.001^{* *}$ \\
4 & Lactoferrin & $0.61 \pm 0.08$ & $0.002^{* *}$ \\
5 & Panax ginseng & $0.71 \pm 0.04$ & $0.040^{*}$ \\
6 & Vitamin B6 & $0.74 \pm 0.02$ & $0.003^{* *}$ \\
7 & Ginkgo biloba extract A & $0.99 \pm 0.14$ & 0.952 \\
8 & Thiamine mononitrate & $1.26 \pm 0.16$ & 0.050 \\
\hline
\end{tabular}

Fold changes of HIF activity by the samples were compared with the value of $\mathrm{CoCl}_{2}$-induced HIF activity in $661 \mathrm{~W}$ cells $\left(n=3\right.$ per sample, $\left.{ }^{*} p<0.05,{ }^{* *} p<0.01\right)$. 


\section{Appendix C}

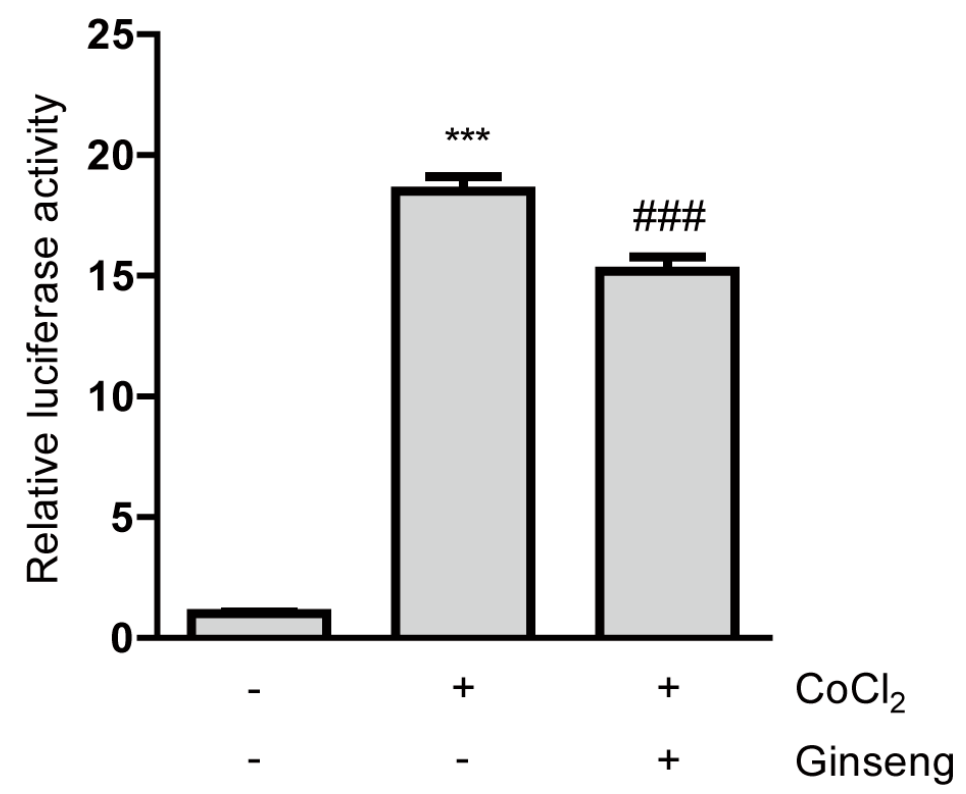

Figure A1. An inhibitory effect of panax ginseng on HIF activity. Quantitative analysis of HIF-reporter luciferase assay using ARPE-19 cells ( $n=3$ per group) showed that ginseng inhibited $\mathrm{CoCl}_{2}$-induced HIF activity. ${ }^{* * *} p<0.001$, \#\#\# $p<0.001$, compared with no treatment and $200 \mu \mathrm{M}$ of $\mathrm{CoCl}_{2}$ treatment, respectively. A bar graph was presented as mean \pm standard deviation. The data were analyzed using one-way ANOVA followed by a Bonferroni post hoc test. Solvent, ginseng: water.

\section{Appendix D}

Table A3. Ingredient information (www.mext.go.jp/a_menu/syokuhinseibun).

\begin{tabular}{ll}
\hline & B1 (thiamine): $3.12 \mathrm{mg}$ \\
& B2 (riboflavin): $0.21 \mathrm{mg}$ \\
& B3 (niacinamide): $34.6 \mathrm{mg}$ \\
Components of vitamin B (in $100 \mathrm{~g}$ of rice bran) & B5 (pantothenic acid): $4.43 \mathrm{mg}$ \\
& B6 (pyridoxine hydrochloride): $3.27 \mathrm{mg}$ \\
& B7 (biotin): $0.04 \mathrm{mg}$ \\
& B9 (folic acid): $0.18 \mathrm{mg}$ \\
\hline
\end{tabular}




\section{Appendix E}

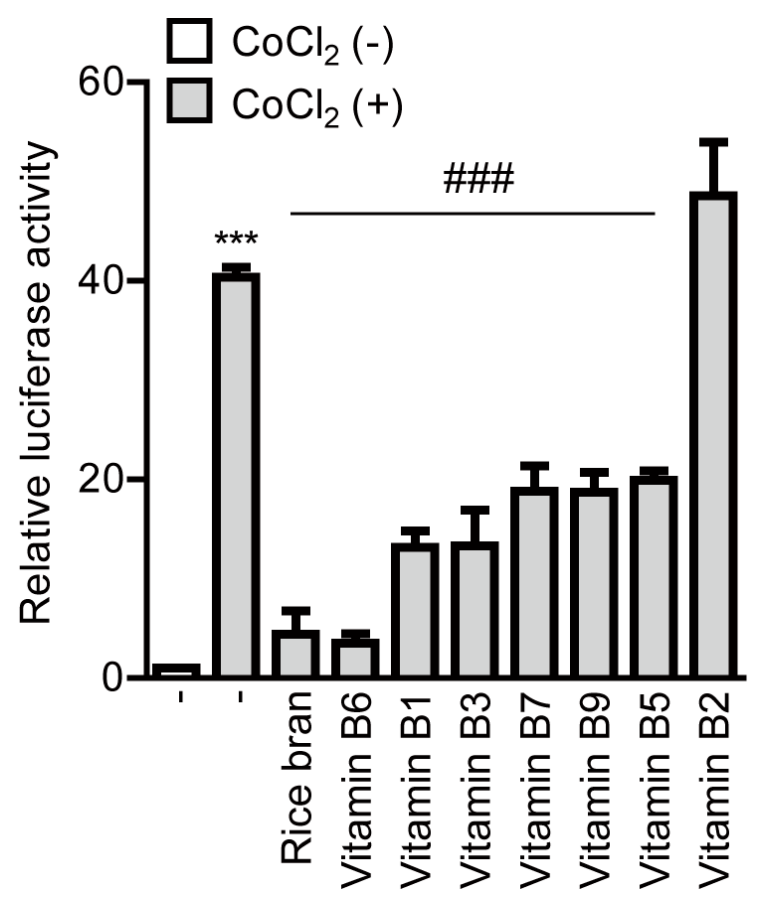

Figure A2. Inhibitory effects of components of vitamin B in rice bran on HIF activity. Quantitative analysis of HIF-reporter luciferase assay using ARPE-19 cells ( $n=3$ per group) showed that vitamin B6 dramatically inhibited $\mathrm{CoCl}_{2}$-induced HIF activity more than any other components in rice bran. ${ }^{* * *} p$ $<0.001$, \#\#\# $p<0.001$, compared with no treatment and $200 \mu \mathrm{M}$ of $\mathrm{CoCl}_{2}$ treatment, respectively. A bar graph was presented as mean \pm standard deviation. The data were analyzed using one-way ANOVA followed by a Bonferroni post hoc test. Solvents, rice bran: DMSO; vitamin B: water.

\section{Appendix F}
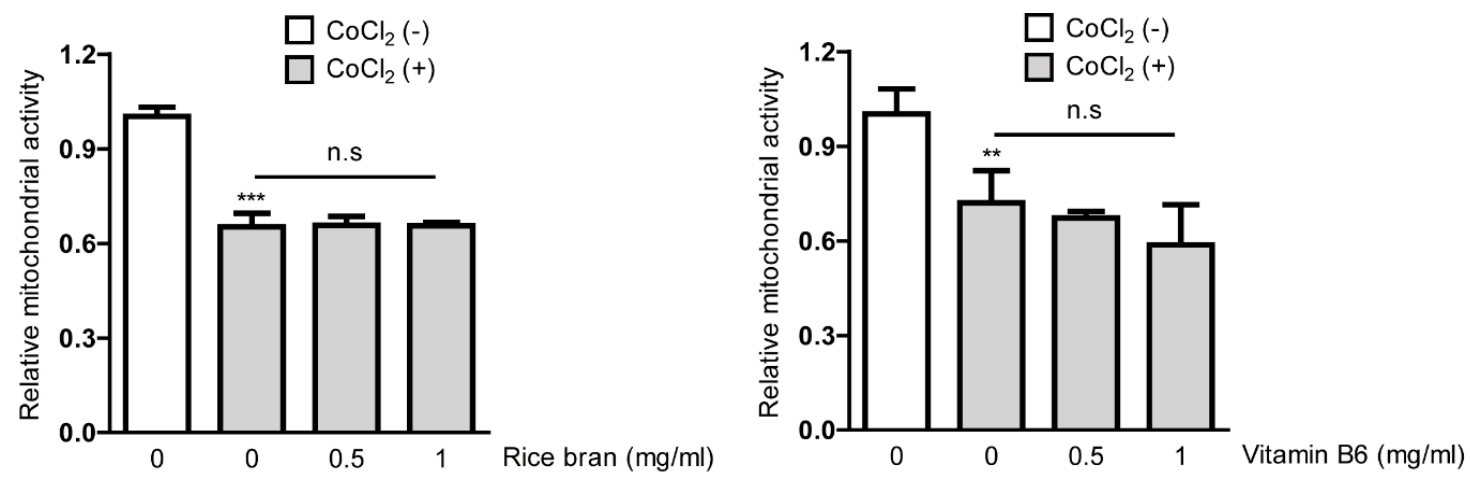

Figure A3. No cytotoxicity of rice bran and vitamin B6. Quantitative analyses ( $n=4$ per group) showed that a significant change in mitochondrial activity was not seen in ARPE-19 cells $12 \mathrm{~h}$ after rice bran or vitamin $\mathrm{B} 6$ treatment under a $\mathrm{CoCl}_{2}$-induced pseudo-hypoxic condition. However, high-dose vitamin B6 $(1 \mathrm{mg} / \mathrm{mL})$ tended to damage mitochondrial activity. ${ }^{* *} p<0.01,{ }^{* * *} p<0.001$, compared with no treatment. Bar graphs were presented as mean \pm standard deviation. The data were analyzed using one-way ANOVA followed by a Bonferroni post hoc test. Solvents, rice bran: DMSO; vitamin B6: water. 


\section{Appendix G}
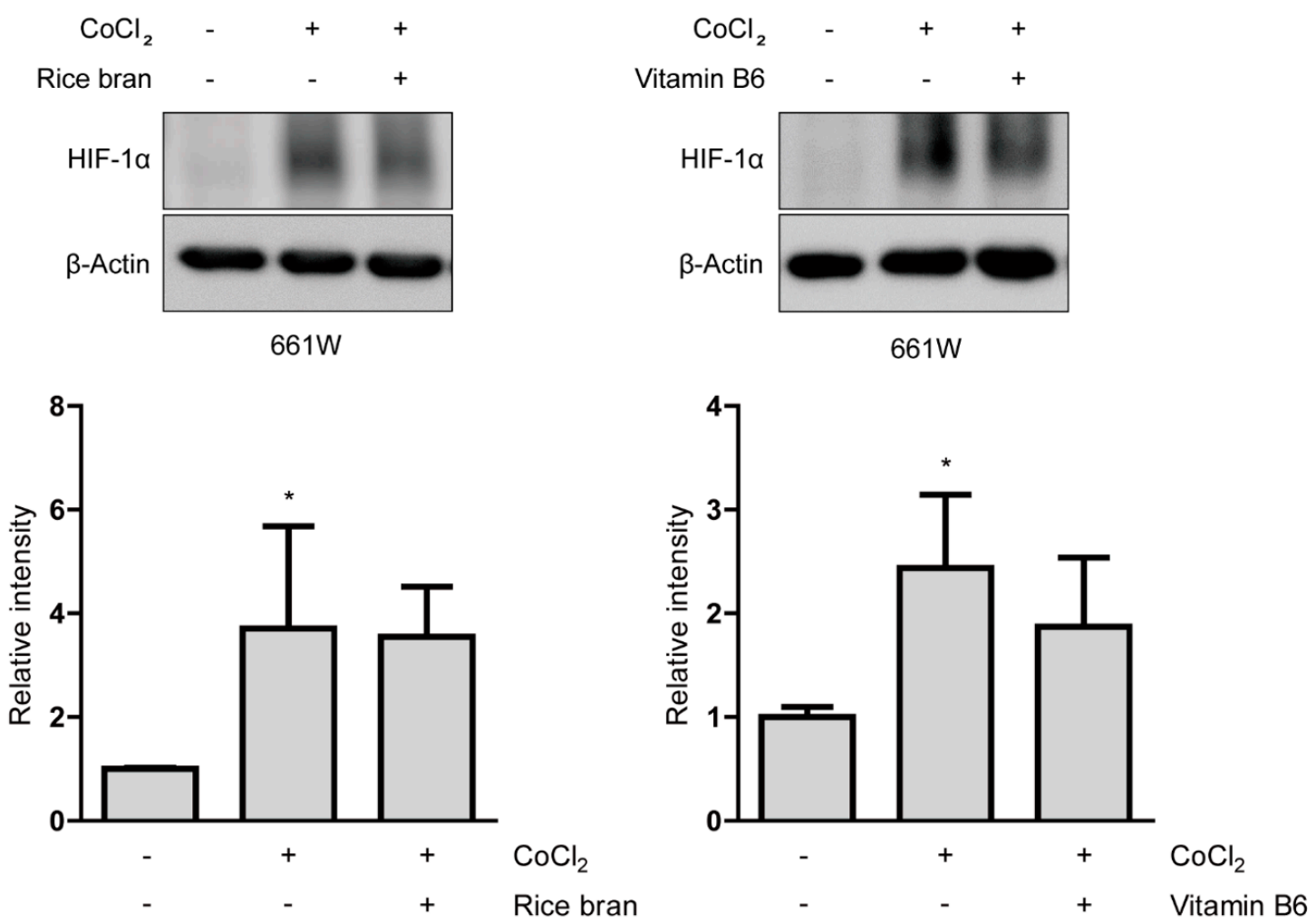

Figure A4. No effect of rice bran and vitamin B6 on HIF- $1 \alpha$ stabilization. Representative immunoblot images and quantitative analyses ( $n=4$ per group) for HIF- $1 \alpha$ and $\beta$-Actin showed that HIF- $1 \alpha$ was stabilized in $661 \mathrm{~W}$ cells under a $\mathrm{CoCl}_{2}$-induced pseudo-hypoxic condition. $1 \mathrm{mg} / \mathrm{mL}$ of rice bran and vitamin B6 did not significantly decrease stabilized HIF- $1 \alpha$ expression. ${ }^{*} p<0.05$, compared with no treatment. Bar graphs were presented as mean \pm standard deviation. The data were analyzed using one-way ANOVA followed by a Bonferroni post hoc test. Solvents, rice bran: DMSO; vitamin B6: water. 


\section{Appendix $\mathrm{H}$}

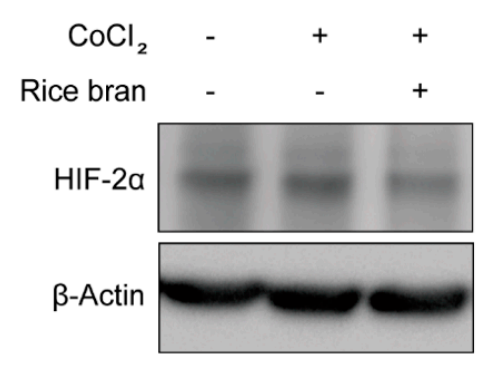

ARPE-19

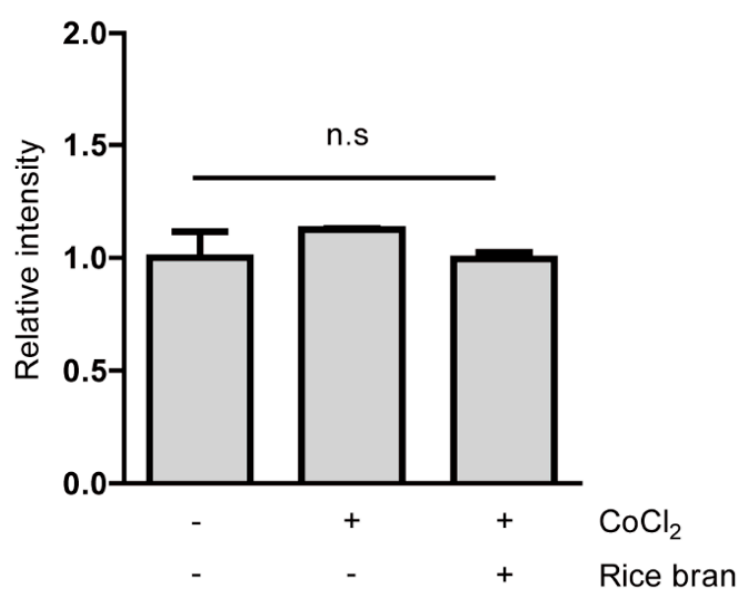

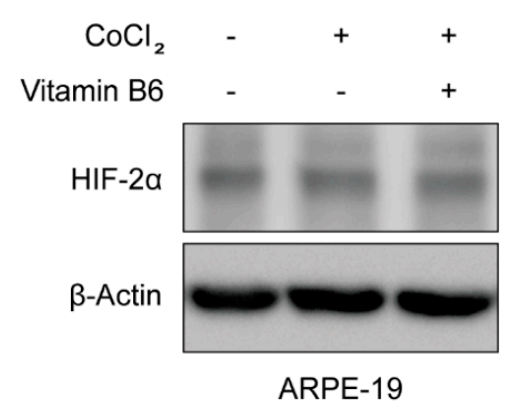

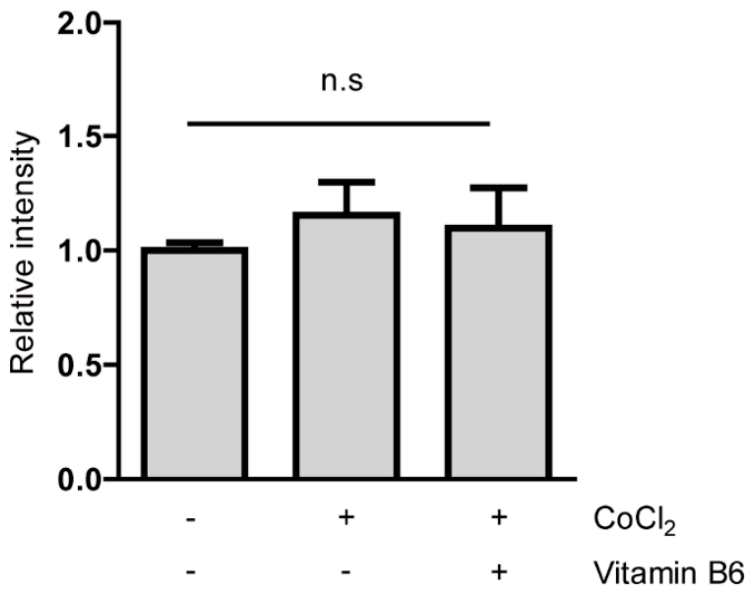

Figure A5. No effect of rice bran and vitamin B6 on HIF-2 $\alpha$ stabilization. Representative immunoblot images and quantitative analyses ( $n=4$ per group) for HIF- $2 \alpha$ and $\beta$-Actin showed that HIF- $2 \alpha$ was not significantly stabilized in ARPE-19 cells under a $\mathrm{CoCl}_{2}$-induced pseudo-hypoxic condition. $1 \mathrm{mg} / \mathrm{mL}$ of rice bran and vitamin $\mathrm{B} 6$ did not significantly change its expression. Bar graphs were presented as mean \pm standard deviation. The data were analyzed using one-way ANOVA followed by a Bonferroni post hoc test. Solvents, rice bran: DMSO; vitamin B6: water. 


\section{Appendix I}
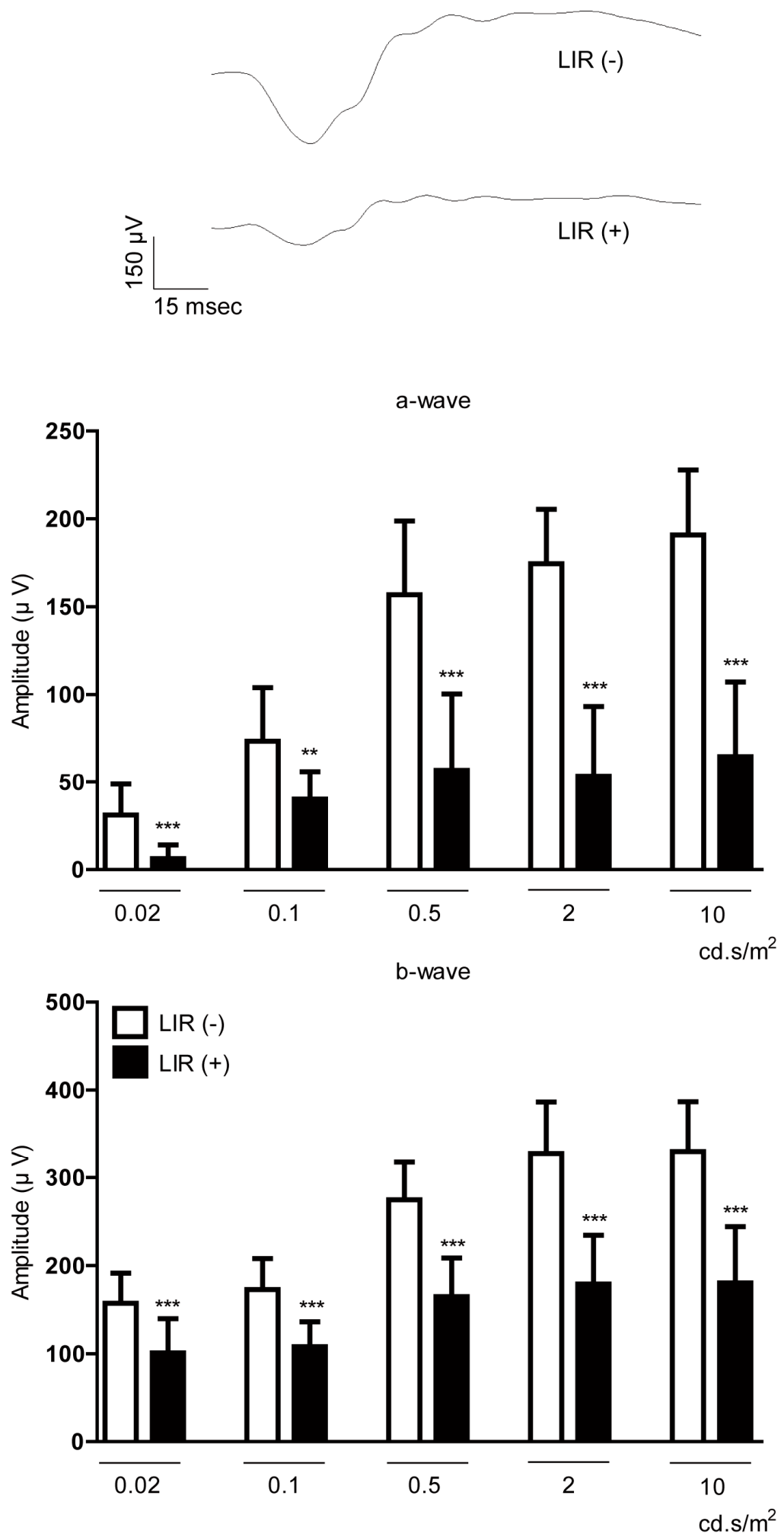

Figure A6. Evaluation of a mouse model of LIR. Representative waveforms of a- and b-waves $\left(2 \mathrm{~cd} . \mathrm{s} / \mathrm{m}^{2}\right)$ and quantitative analyses showed that the light exposure (3000 lux) significantly decreased the amplitudes of a-wave and $b$-wave in the retina ( $n=6$ per group, 12 eyeballs per group). ${ }^{* *} p<0.01$, *** $p<0.001$. Bar graphs were presented as mean \pm standard deviation. The data were analyzed using Student's $t$-test. 


\section{References}

1. Ding, J.; Wong, T.Y. Current Epidemiology of Diabetic Retinopathy and Diabetic Macular Edema. Curr. Diabetes Rep. 2012, 12, 346-354. [CrossRef] [PubMed]

2. Resnikoff, S.; Pascolini, D.; Etya'ale, D.; Kocur, I.; Pararajasegaram, R.; Pokharel, G.P.; Mariotti, S.P. Global data on visual impairment in the year 2002. Bull. World Health Organ. 2004, 82, 844-851. [PubMed]

3. Hyman, L.G.; Lilienfeld, A.M.; Ferris, F.L., 3rd; Fine, S.L. Senile macular degeneration: A case-control study. Am. J. Epidemiol. 1983, 118, 213-227. [CrossRef] [PubMed]

4. Fogli, S.; Del Re, M.; Rofi, E.; Posarelli, C.; Figus, M.; Danesi, R. Clinical pharmacology of intravitreal anti-VEGF drugs. Eye 2018, 32, 1010-1020. [CrossRef]

5. Ozaki, H.; Seo, M.S.; Ozaki, K.; Yamada, H.; Yamada, E.; Okamoto, N.; Hofmann, F.; Wood, J.M.; Campochiaro, P.A. Blockade of vascular endothelial cell growth factor receptor signaling is sufficient to completely prevent retinal neovascularization. Am. J. Pathol. 2000, 156, 697-707. [CrossRef]

6. Cabral, T.; Mello, L.G.M.; Lima, L.H.; Polido, J.; Regatieri, C.V.; Belfort, R.; Mahajan, V.B. Retinal and choroidal angiogenesis: A review of new targets. Int. J. Retin. Vitr. 2017, 3, 31. [CrossRef]

7. Yang, S.; Zhao, J.; Sun, X. Resistance to anti-VEGF therapy in neovascular age-related macular degeneration: A comprehensive review. Drug Des. Devel. Ther. 2016, 10, 1857-1867. [CrossRef]

8. Kaelin, W.G.; Ratcliffe, P.J. Oxygen Sensing by Metazoans: The Central Role of the HIF Hydroxylase Pathway. Mol. Cell 2008, 30, 393-402. [CrossRef]

9. Mole, D.R.; Blancher, C.; Copley, R.R.; Pollard, P.J.; Gleadle, J.M.; Ragoussis, J.; Ratcliffe, P.J. Genome-wide association of hypoxia-inducible factor (HIF)-1alpha and HIF-2alpha DNA binding with expression profiling of hypoxia-inducible transcripts. J. Biol. Chem. 2009, 284, 16767-16775. [CrossRef]

10. Majmundar, A.J.; Wong, W.J.; Simon, M.C. Hypoxia-Inducible Factors and the Response to Hypoxic Stress. Mol. Cell 2010, 40, 294-309. [CrossRef] [PubMed]

11. Krock, B.L.; Skuli, N.; Simon, M.C. Hypoxia-induced angiogenesis: Good and evil. Genes Cancer 2011, 2, 1117-1133. [CrossRef] [PubMed]

12. Ohno, H.; Shirato, K.; Sakurai, T.; Ogasawara, J.; Sumitani, Y.; Sato, S.; Imaizumi, K.; Ishida, H.; Kizaki, T. Effect of exercise on HIF-1 and VEGF signaling. J. Phys. Fit. Sports Med. 2012, 1, 5-16. [CrossRef]

13. Inoue, Y.; Yanagi, Y.; Matsuura, K.; Takahashi, H.; Tamaki, Y.; Araie, M. Expression of hypoxia-inducible factor 1alpha and 2alpha in choroidal neovascular membranes associated with age-related macular degeneration. Br. J. Ophthalmol. 2007, 91, 1720-1721. [CrossRef] [PubMed]

14. Sheridan, C.M.; Pate, S.; Hiscott, P.; Wong, D.; Pattwell, D.M.; Kent, D. Expression of hypoxia-inducible factor $-1 \alpha$ and $-2 \alpha$ in human choroidal neovascular membranes. Graefe's Arch. Clin. Exp. Ophthalmol. 2009, 247, 1361-1367. [CrossRef] [PubMed]

15. Ibuki, M.; Shoda, C.; Miwa, Y.; Ishida, A.; Tsubota, K.; Kurihara, T. Lactoferrin Has a Therapeutic Effect via HIF Inhibition in a Murine Model of Choroidal Neovascularization. Front. Pharmacol. 2020, 11, 174. [CrossRef] [PubMed]

16. Ibuki, M.; Shoda, C.; Miwa, Y.; Ishida, A.; Tsubota, K.; Kurihara, T. Therapeutic Effect of Garcinia cambogia Extract and Hydroxycitric Acid Inhibiting Hypoxia-Inducible Factor in a Murine Model of Age-Related Macular Degeneration. Int. J. Mol. Sci. 2019, 20, 5049. [CrossRef]

17. Shoda, C.; Miwa, Y.; Nimura, K.; Okamoto, K.; Yamagami, S.; Tsubota, K.; Kurihara, T. Hypoxia-Inducible Factor Inhibitors Derived from Marine Products Suppress a Murine Model of Neovascular Retinopathy. Nutrients 2020, 12, 1055. [CrossRef]

18. Miwa, Y.; Hoshino, Y.; Shoda, C.; Jiang, X.; Tsubota, K.; Kurihara, T. Pharmacological HIF inhibition prevents retinal neovascularization with improved visual function in a murine oxygen-induced retinopathy model. Neurochem. Int. 2019, 128, 21-31. [CrossRef]

19. Lee, D.; Miwa, Y.; Wu, J.; Shoda, C.; Jeong, H.; Kawagishi, H.; Tsubota, K.; Kurihara, T. A Fairy Chemical Suppresses Retinal Angiogenesis as a HIF Inhibitor. Biomolecules 2020, 10, 1405. [CrossRef]

20. Kunimi, H.; Miwa, Y.; Inoue, H.; Tsubota, K.; Kurihara, T. A Novel HIF Inhibitor Halofuginone Prevents Neurodegeneration in a Murine Model of Retinal Ischemia-Reperfusion. Int. J. Mol. Sci. 2019, 20, 3171. [CrossRef]

21. Chew, E.Y. Nutrition effects on ocular diseases in the aging eye. Investig. Ophthalmol. Vis. Sci. 2013, 54, ORSF42-ORSF47. [CrossRef] [PubMed] 
22. Gómez-Pinilla, F. Brain foods: The effects of nutrients on brain function. Nat. Rev. Neurosci. 2008, 9, 568-578. [CrossRef] [PubMed]

23. Lawrenson, J.G.; Downie, L.E. Nutrition and Eye Health. Nutrients 2019, 11, 2123. [CrossRef] [PubMed]

24. McCann, J.C.; Ames, B.N. Is docosahexaenoic acid, an n-3 long-chain polyunsaturated fatty acid, required for development of normal brain function? An overview of evidence from cognitive and behavioral tests in humans and animals. Am. J. Clin. Nutr. 2005, 82, 281-295. [CrossRef]

25. Hanyuda, A.; Rosner, B.A.; Wiggs, J.L.; Willett, W.C.; Tsubota, K.; Pasquale, L.R.; Kang, J.H. Low-carbohydrate-diet scores and the risk of primary open-angle glaucoma: Data from three US cohorts. Eye 2020, 34, 1465-1475. [CrossRef]

26. Kurihara, T.; Omoto, M.; Noda, K.; Ebinuma, M.; Kubota, S.; Koizumi, H.; Yoshida, S.; Ozawa, Y.; Shimmura, S.; Ishida, S.; et al. Retinal phototoxicity in a novel murine model of intraocular lens implantation. Mol. Vis. 2009, 15, 2751-2761.

27. Malek, G.; Busik, J.; Grant, M.B.; Choudhary, M. Models of retinal diseases and their applicability in drug discovery. Expert Opin. Drug Discov. 2018, 13, 359-377. [CrossRef]

28. Sayyad, Z.; Sirohi, K.; Radha, V.; Swarup, G. $661 \mathrm{~W}$ is a retinal ganglion precursor-like cell line in which glaucoma-associated optineurin mutants induce cell death selectively. Sci. Rep. 2017, 7, 16855. [CrossRef]

29. Hellinen, L.; Hagström, M.; Knuutila, H.; Ruponen, M.; Urtti, A.; Reinisalo, M. Characterization of artificially re-pigmented ARPE-19 retinal pigment epithelial cell model. Sci. Rep. 2019, 9, 13761. [CrossRef]

30. Spilsbury, K.; Garrett, K.L.; Shen, W.Y.; Constable, I.J.; Rakoczy, P.E. Overexpression of vascular endothelial growth factor (VEGF) in the retinal pigment epithelium leads to the development of choroidal neovascularization. Am. J. Pathol. 2000, 157, 135-144. [CrossRef]

31. Blaauwgeers, H.G.; Holtkamp, G.M.; Rutten, H.; Witmer, A.N.; Koolwijk, P.; Partanen, T.A.; Alitalo, K.; Kroon, M.E.; Kijlstra, A.; van Hinsbergh, V.W.; et al. Polarized vascular endothelial growth factor secretion by human retinal pigment epithelium and localization of vascular endothelial growth factor receptors on the inner choriocapillaris. Evidence for a trophic paracrine relation. Am. J. Pathol. 1999, 155, 421-428. [CrossRef]

32. Ablonczy, Z.; Dahrouj, M.; Marneros, A.G. Progressive dysfunction of the retinal pigment epithelium and retina due to increased VEGF-A levels. FASEB J. 2014, 28, 2369-2379. [CrossRef] [PubMed]

33. Forooghian, F.; Razavi, R.; Timms, L. Hypoxia-inducible factor expression in human RPE cells. Br. J. Ophthalmol. 2007, 91, 1406-1410. [CrossRef] [PubMed]

34. Takei, A.; Ekström, M.; Mammadzada, P.; Aronsson, M.; Yu, M.; Kvanta, A.; André, H. Gene Transfer of Prolyl Hydroxylase Domain 2 Inhibits Hypoxia-inducible Angiogenesis in a Model of Choroidal Neovascularization. Sci. Rep. 2017, 7, 42546. [CrossRef]

35. Bahrami, B.; Shen, W.; Zhu, L.; Zhang, T.; Chang, A.; Gillies, M.C. Effects of VEGF inhibitors on human retinal pigment epithelium under high glucose and hypoxia. Clin. Exp. Ophthalmol. 2019, 47, 1074-1081. [CrossRef]

36. Chu, C.-Y.; Jin, Y.-T.; Zhang, W.; Yu, J.; Yang, H.-P.; Wang, H.-Y.; Zhang, Z.-J.; Liu, X.-P.; Zou, Q. CA IX is upregulated in $\mathrm{CoCl} 2$-induced hypoxia and associated with cell invasive potential and a poor prognosis of breast cancer. Int. J. Oncol. 2016, 48, 271-280. [CrossRef]

37. Okamoto, T.; Kawashima, H.; Osada, H.; Toda, E.; Homma, K.; Nagai, N.; Imai, Y.; Tsubota, K.; Ozawa, Y. Dietary Spirulina Supplementation Protects Visual Function From Photostress by Suppressing Retinal Neurodegeneration in Mice. Transl. Vis. Sci. Technol. 2019, 8, 20. [CrossRef]

38. Sasaki, M.; Yuki, K.; Kurihara, T.; Miyake, S.; Noda, K.; Kobayashi, S.; Ishida, S.; Tsubota, K.; Ozawa, Y. Biological role of lutein in the light-induced retinal degeneration. J. Nutr. Biochem. 2012, 23, 423-429. [CrossRef]

39. Gul, K.; Yousuf, B.; Singh, A.K.; Singh, P.; Wani, A.A. Rice bran: Nutritional values and its emerging potential for development of functional food-A review. Bioact. Carbohydr. Diet. Fibre 2015, 6, 24-30. [CrossRef]

40. Park, H.Y.; Lee, K.W.; Choi, H.D. Rice bran constituents: Immunomodulatory and therapeutic activities. Food Funct. 2017, 8, 935-943. [CrossRef]

41. Kurihara, T.; Westenskow, P.D.; Bravo, S.; Aguilar, E.; Friedlander, M. Targeted deletion of Vegfa in adult mice induces vision loss. J. Clin. Investig. 2012, 122, 4213-4217. [CrossRef] [PubMed]

42. Bhutto, I.; Lutty, G. Understanding age-related macular degeneration (AMD): Relationships between the photoreceptor/retinal pigment epithelium/Bruch's membrane/choriocapillaris complex. Mol. Asp. Med. 2012, 33, 295-317. [CrossRef] [PubMed] 
43. Lehmann, G.L.; Benedicto, I.; Philp, N.J.; Rodriguez-Boulan, E. Plasma membrane protein polarity and trafficking in RPE cells: Past, present and future. Exp. Eye Res. 2014, 126, 5-15. [CrossRef] [PubMed]

44. Ford, K.M.; Saint-Geniez, M.; Walshe, T.; Zahr, A.; D'Amore, P.A. Expression and role of VEGF in the adult retinal pigment epithelium. Investig. Ophthalmol. Vis. Sci. 2011, 52, 9478-9487. [CrossRef] [PubMed]

45. Sparrow, J.R.; Ueda, K.; Zhou, J. Complement dysregulation in AMD: RPE-Bruch's membrane-choroid. Mol. Asp. Med. 2012, 33, 436-445. [CrossRef]

46. Noël, A.; Jost, M.; Lambert, V.; Lecomte, J.; Rakic, J.-M. Anti-angiogenic therapy of exudative age-related macular degeneration: Current progress and emerging concepts. Trends Mol. Med. 2007, 13, 345-352. [CrossRef] [PubMed]

47. Espinosa-Heidmann, D.G.; Reinoso, M.A.; Pina, Y.; Csaky, K.G.; Caicedo, A.; Cousins, S.W. Quantitative enumeration of vascular smooth muscle cells and endothelial cells derived from bone marrow precursors in experimental choroidal neovascularization. Exp. Eye Res. 2005, 80, 369-378. [CrossRef]

48. Spaide, R.F. Rationale for combination therapies for choroidal neovascularization. Am. J. Ophthalmol. 2006, 141, 149-156. [CrossRef]

49. Mansour, S.E.; Browning, D.J.; Wong, K.; Flynn, H.W., Jr.; Bhavsar, A.R. The Evolving Treatment of Diabetic Retinopathy. Clin. Ophthalmol. 2020, 14, 653-678. [CrossRef]

50. Grunwald, J.E.; Daniel, E.; Huang, J.; Ying, G.-S.; Maguire, M.G.; Toth, C.A.; Jaffe, G.J.; Fine, S.L.; Blodi, B.; Klein, M.L.; et al. Risk of geographic atrophy in the comparison of age-related macular degeneration treatments trials. Ophthalmology 2014, 121, 150-161. [CrossRef]

51. Saint-Geniez, M.; Maharaj, A.S.R.; Walshe, T.E.; Tucker, B.A.; Sekiyama, E.; Kurihara, T.; Darland, D.C.; Young, M.J.; D'Amore, P.A. Endogenous VEGF Is Required for Visual Function: Evidence for a Survival Role on Müller Cells and Photoreceptors. PLoS ONE 2008, 3, e3554. [CrossRef]

52. Mohamed, Q.; Gillies, M.C.; Wong, T.Y. Management of Diabetic RetinopathyA Systematic Review. JAMA 2007, 298, 902-916. [CrossRef] [PubMed]

53. Simó, R.; Hernández, C. Advances in the medical treatment of diabetic retinopathy. Diabetes Care 2009, 32, 1556-1562. [CrossRef] [PubMed]

54. Giovannitti, J.A.; Trapp, L.D. Adult sedation: Oral, rectal, IM, IV. Anesth. Prog. 1991, 38, 154-171.

Publisher's Note: MDPI stays neutral with regard to jurisdictional claims in published maps and institutional affiliations.

(C) 2020 by the authors. Licensee MDPI, Basel, Switzerland. This article is an open access article distributed under the terms and conditions of the Creative Commons Attribution (CC BY) license (http://creativecommons.org/licenses/by/4.0/). 